PALEO

Revue d'archéologie préhistorique

$24 \mid 2013$

Varia

\title{
Functional and spatial diversity of Palaeolithic and Mesolithic camps around Lublin in Polesia (Poland)
}

Diversité fonctionnelle et spatiale des campements paléolithiques et mésolithiques dans la Polésie de Lublin (Pologne)

\section{Tomasz Boron}

\section{CpenEdition}

\section{Journals}

Electronic version

URL: http://journals.openedition.org/paleo/2856

DOI: $10.4000 /$ paleo.2856

ISSN: $2101-0420$

\section{Publisher}

SAMRA

Printed version

Date of publication: 15 December 2013

Number of pages: 47-78

ISSN: 1145-3370

\section{Electronic reference}

Tomasz Boron, «Functional and spatial diversity of Palaeolithic and Mesolithic camps around Lublin in Polesia (Poland) », PALEO [Online], 24 | 2013, Online since 18 September 2015, connection on 07 July 2020. URL : http://journals.openedition.org/paleo/2856 ; DOI : https://doi.org/10.4000/paleo. 2856

This text was automatically generated on 7 July 2020.

\section{(c) $(1) \odot$}

PALEO est mis à disposition selon les termes de la licence Creative Commons Attribution - Pas d'Utilisation Commerciale - Pas de Modification 4.0 International. 


\title{
Functional and spatial diversity of Palaeolithic and Mesolithic camps around Lublin in Polesia (Poland)
}

Diversité fonctionnelle et spatiale des campements paléolithiques et mésolithiques dans la Polésie de Lublin (Pologne)

\author{
Tomasz Boron
}

\section{Introduction}

1 The functional and spatial analysis that is the subject of this article is based on the study of the archaeological material uncovered during work on the site of Nieborowa in southeastern Poland (fig. 1-1). The group of the Nieborowa sites (I, II, III) is at the limit of three regions, distinct by their geography as well as their environment and landscapes: Pagóry Chełmskie (Chełm hills), Pojezierze ŁĘczyńsko - Włodawskie (lakes of ŁĘczna and Włodawa) and Obniżenie Dubienki (lower section of Dubienka) (fig. 1-2).

2 The basin of the Vistula River, in its southern and central zones, represents the denser occupation area of the Janislavice culture (Kozlowski, 2007 - p. 111) (fig. 1 -1).

3 The archaeological site of Nieborowa was discovered in the years 1962-1963 when the History of Material Culture Institute (currently IEA PAN: the Institute of Archaeology and Ethnology of the Polish Academy of Sciences) organized surface work under the direction of Professor Waldemar Chmielewski.

4 Halina Mackiewicz from IAE PAN conducted the archaeological excavations between 1964 and 1977. They yielded rich flint and ceramic materials, highly diverse and from different cultures, from the final Palaeolithic to the first Iron Age included.

5 The site of Nieborowa I is located on a sandy slope: in such a spatial configuration, only small burnt animal bones and charcoals survived, without other organic remains. Archaeological material was identified up to $120 \mathrm{~cm}$ below the surface. 


$$
\text { valuable and reliable source for the study of spatial planning in the Stone and Metal }
$$
ages settlements.

7 A key criterion in the reconstruction and the interpretation of the habitation structures is the homogeneity of portable objects that, when they appear as small compact concentrations of flint, are a strong argument proving their cultural uniformity (Schild, Marczak, Królik 1975 - p 37; Grön 1987 - p. 65). Withstanding degradation better than organic objects (Andrefsky Jr. 2009 - p. 65), lithic objects usually represent the majority of the artefacts found in archaeological sites and remain, by far, the material remains the most likely to provide data for the spatial analysis of settlements.

Based on the study of the lithic remains, our spatial analysis relies on their horizontal distribution (Schild 1980 - p. 79-80), and in particular on the distribution of the waste from tool manufacturing (burins, microburins). It is commonly believed that they show where the tools were made (Olive, 1997 - p. 91-92; Fiedorczuk 2006- p. 30) because, as a rule, they are found in primary deposition - primary refuse (Schiffer 1976 - p. 30). Given their small sizes, they are less sensitive to external factors that may cause horizontal dislocations (Olausson 1986 - p. 21).

9 The relationship between the deposition of flint objects and their place of use is much more complex, as evidenced by the observed spatial distribution of remains in level 4 , trench 9, in Całowanie where, when the work was finished, the tools were discarded (Schild 1984 - p. 230, fig 4. -2, 3).

The method that allowed recognizing the different areas of activities, then recording them and defining their spatio- temporal relationships is that of lithic refitting (Tomaszewski 1986 - p. 257-273), as evidenced for example by the work done on the site of Meer II (Cahen, Keeley, Van Noten 1979 - fig. 8, 9; Cahen 1984 - p. 247). In our study, according to the proposal of E. Cziesla (1990 - p. 9-10), the links between the refitted artefacts are indicated by three different lines.

11 The portable objects considered here represent different phases of occupation of the Nieborowa microregion. The oldest belong to Mazovian groups (Swiderian culture) and are dated from about 10,800 to 9,700 BP (Schild 1996 - p. 135). Our choice fell on two of them, discovered in trenches 4 and 9 of the Nieborowa I site (fig. 1-3). The analysis also included Mesolithic artefacts from the Janislavice culture between 7,300 BP (Szymczak 2003 - p. 13-14) and about 5,600 - 5,500 BP.

12 According to the periodization of the Janislavician culture (Galinski 1997 - p. 204-211, 2002 - p. 280-289), the oldest horizon gathers assemblages without trapezes that could be dated to the beginning of the Atlantic horizon (7,500 BP -7,000 BP) (Galinski, $2002-$ p. 285; Kozlowski 1972 - p. 159, 1989 - p. 156). This type of assemblage, besides Nieborowa, is found on two other sites: the tomb of Janislavice (Chmielewska $1954-\mathrm{p}$. 23-48) and of Wistka Szlachecka II/1960 (Schild, Marczak, Królik 1975 - p 127-129).

The next step in the development of the Janislavician culture is marked by the presence of classical industries with trapezes evidenced here by the material from trench 8.

The remains from trenches 1 and 2 (site of Nieborowa III) were classified among the chronologically most recent Janislavician lithic material (sometimes called assemblages of the Baraki Stare type) and are characterized by the presence of small and narrow triangles (Galinski, 2002 - p. 287).

PALEO, 24 | 2013 
Assemblages dating from the final Atlantic period represent the last step of the Mesolithic occupation in Nieborowa. Their common feature is that trapezes and tools on flakes (end scrapers, retouched flakes, sides scrapers) are neatly dominating.

The dates obtained on charcoal $(7,250 \pm 50 \mathrm{BP}\{\mathrm{Poz}-18718\}$ - trench 2; $7120 \pm 70 \mathrm{BP}\{\mathrm{Gd}$ II61\} - trench 6; 7,010 $\pm 40 \mathrm{BP}\{\mathrm{Poz}-18719\}$ - trench 9) show that the beginnings of the Janislavician occupation of Nieborowa are contemporary with the end of the early phase of the Atlantic. The age of the trapeze industries (Postjanislavician industries) of trench 2 of the site of Nieborowa I is situated in the middle of the final phase of this period 5,730 $\pm 130 \mathrm{BP}\{144\} \mathrm{Gd}$.

The spatial and functional analysis of the occupations of the Janislavician culture in Nieborowa were done on the basis of the flint material from trenches 4 and 7 (classical assemblages, without trapezes) as well as from trenches 2 and 3 (Postjanislavician industries) (fig. 1-3).

Figure 1 - Geographical location of the Nieborowa site ; 2 - Location of the Nieborowa site in Lublin Polesie ; 3 - Nieborowa I. General plan of the trenches.

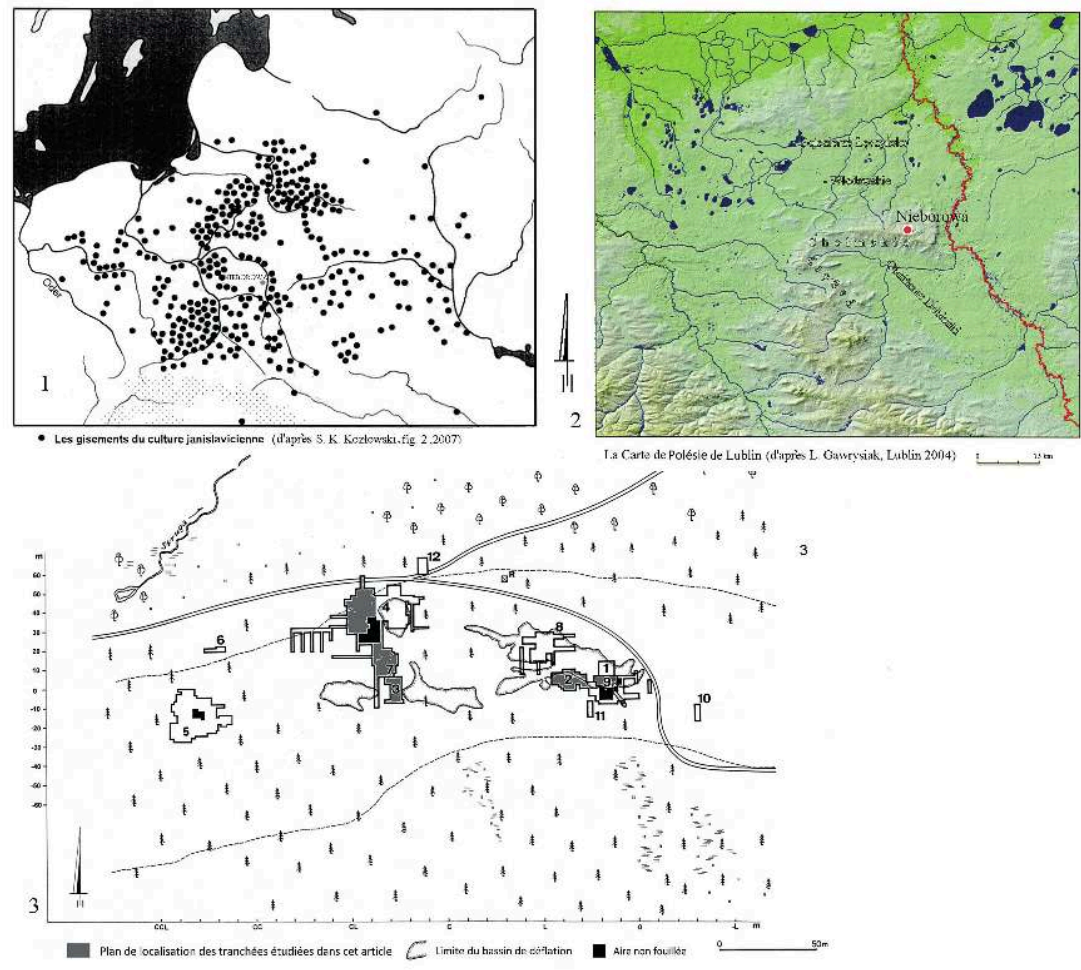

\section{1 - Spatial and functional analysis}

For clarity, the spatial and functional analysis of the occupations will be presented in chronological order.

\section{1 - Mazovian occupation}

Trench 4, measuring 757 sq. m, was explored during the 1965-1967 campaigns. It was divided into three zones: sectors I, II and a deflation area. 
Sector I has two flint concentrations called A and C. Sector II has a single concentration, called B. The spatial analysis will focus on the sectors I (Mesolithic only, Janislavician culture) and II (Palaeolithic - Mazovian occupation- and Mesolithic -Janislavician culture) (fig. 2-1).

Figure 2 - Nieborowa I. 1 -Plan of sectors I and II in the trench $24 ; 2$ - trench 4, sector II. Mapping of finds. Palaeolithic artifacts are in green, Mesolithic in blue.

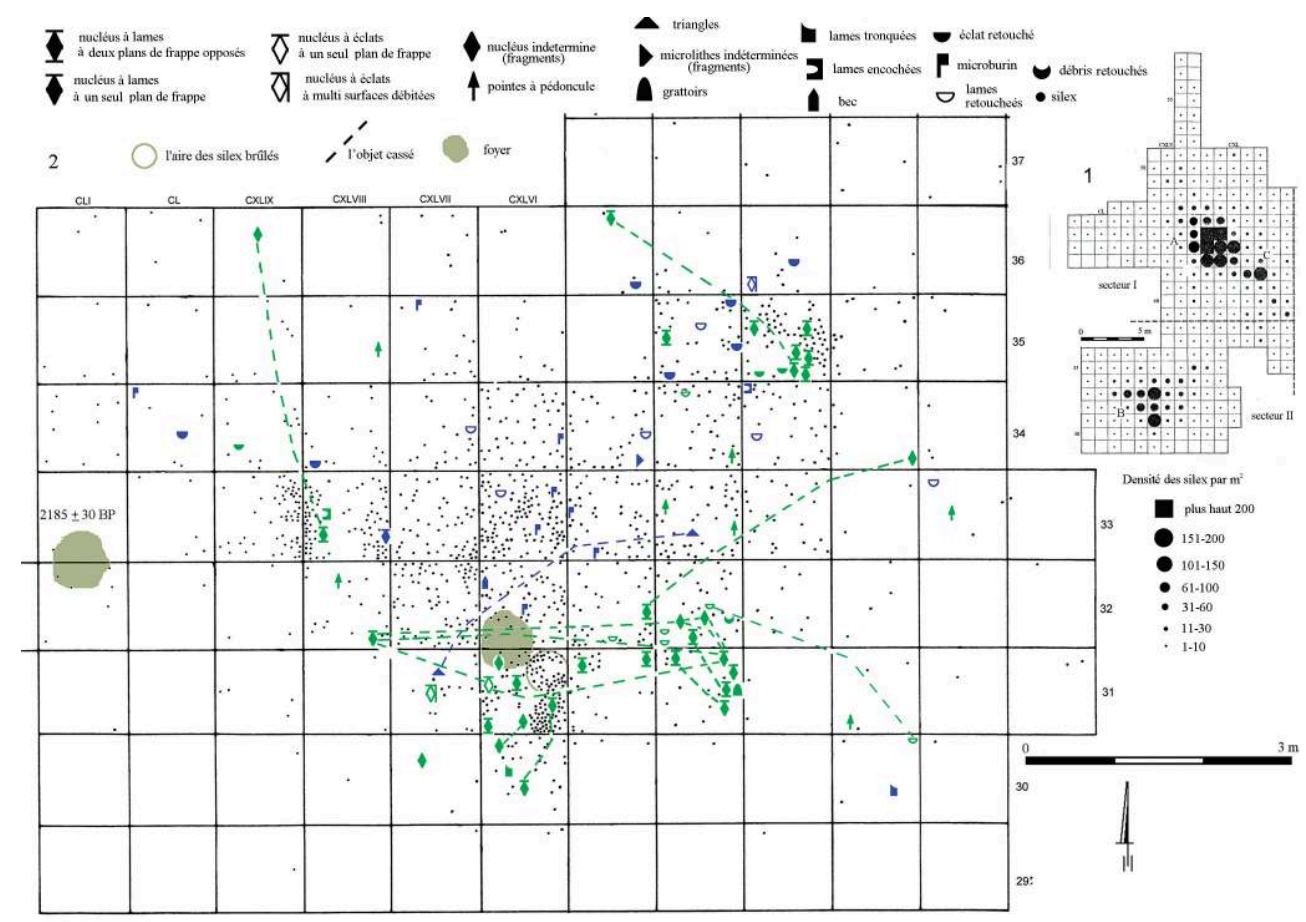

\subsection{1 - Trench 4 Sector II}

Sector II is located in the southern part of the trench. The lithic material formed in this location a fairly large concentration (30 sq. $\mathrm{m}$ ), designated by the letter $\mathrm{B}$, and characterized by a fairly regular distribution of artefacts (fig. 2-2). The archaeological material allowed concluding to the presence of traces of Mazovian and Janislavician occupations. The Mazovian inventory records eleven hafted points (fig. 5 to 3.8), one scraper (fig. 5-9), a notched blade (fig. 5-10), retouched flakes and blades, cores and blanks (flakes and blades) (table 1). 
Table 1 - List of the mazovian artifacts flint.

\begin{tabular}{|c|c|c|}
\hline & $\begin{array}{l}\text { Tranchée } 4 \\
\text { (secteur II) }\end{array}$ & Tranchée 9 \\
\hline & \multicolumn{2}{|c|}{ Nucléus } \\
\hline $\begin{array}{l}\text { Nucléus à lames à deux plans de frappe } \\
\text { opposés }\end{array}$ & 14 & 9 \\
\hline Nucléus à lames à un seul plan de frappe & 14 & \\
\hline Nucléus à éclats à un seul plan de frappe & 2 & \\
\hline Nucléus indéterminé (fragments) & 1 & \\
\hline \multicolumn{3}{|l|}{ Supports éclats } \\
\hline Ėclats & 203 & 154 \\
\hline $\begin{array}{l}\text { Ravivages de plan de frappe } \\
\text { Éclat à crête }\end{array}$ & 14 & $\begin{array}{c}28 \\
1\end{array}$ \\
\hline \multicolumn{3}{|l|}{ Supports laminaires } \\
\hline Lames & 123 & 89 \\
\hline Lames à crête & 36 & 12 \\
\hline Chasse-lame & 5 & 1 \\
\hline Ravivages de plan de frappe & 1 & \\
\hline $\begin{array}{l}\text { Lames sur nucléus à deux plans } \\
\text { de frappe opposés }\end{array}$ & 2 & 2 \\
\hline \multicolumn{3}{|c|}{ Fragments de lames } \\
\hline proximales & 85 & 65 \\
\hline centrales & 78 & 44 \\
\hline distales & 58 & 45 \\
\hline \multicolumn{3}{|l|}{ Outils } \\
\hline Pointes à pédoncules & 11 & 2 \\
\hline Grattoirs & 1 & 1 \\
\hline Lames tronquées & 1 & \\
\hline Lames encochées & 1 & \\
\hline Lames retouchées & 5 & 5 \\
\hline Ėclats retouchés & 3 & \\
\hline Débris retouchés & 1 & \\
\hline
\end{tabular}

22 Four knapping stations (fig. 3-1 to 4) belong to this occupation. They contain waste from core fashioning and debitage. Two other stations (A, B; fig 2-1) are distinguished by products that have been transferred to a location about $10 \mathrm{~m}$ away, located in sector I (Boroń 2006 - p. 20-21). Twelve blocks have been refitted; among them, five allowed locating the knapping stations (flints from knapped cores were left behind) and seven illustrated the spatial relationships between the place of debitage in concentration B and the secondary deposit, the remote waste is located in sector I (fig. 3-1, 2, 3, 4). 
Figure 3 - Nieborowa I, trench 4, sector II. Mazovian. Plan of location refitting flint.

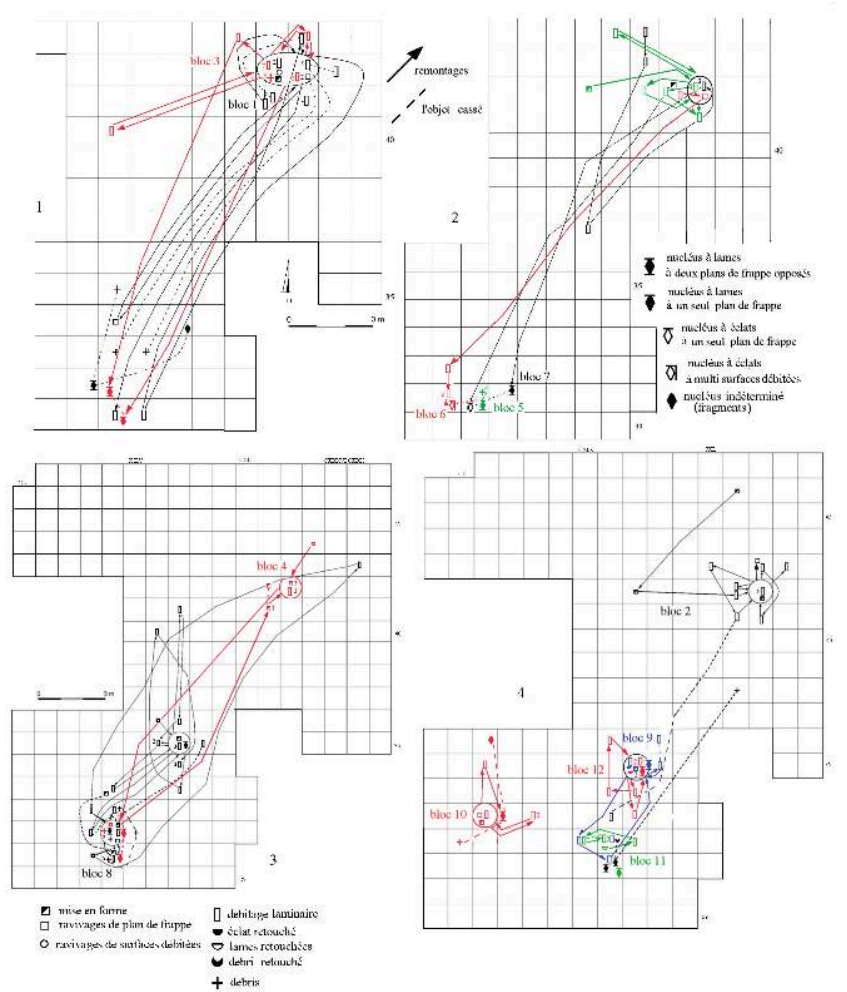

23 The lithic material allows to show the existence of a complete cycle of debitage, from rough-outs and shaping up to the final stage of exploitation (fig. 4-1, 2, 3). The cores remained in place, where they were knapped, which is also the case for blocks $1,2,3,4$, 5, 6 and 7 whose blanks were discarded. 
Figure 4 - Nieborowa I, trench 4, sector II. Mazovien. Refitted block $n^{\circ} 1 ; 2$ - refitted block $n^{\circ} 3 ; 3$ refitted block $n^{\circ} 5$.

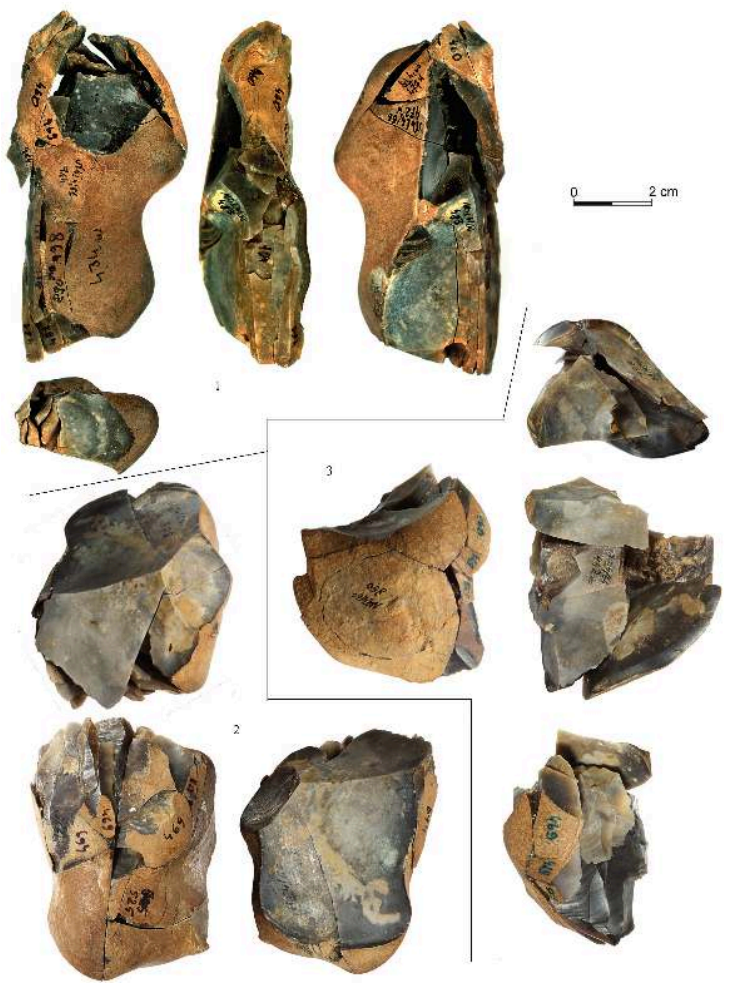

24 The clearing up of lithic material is known on many Palaeolithic sites. It may be related to surface cleaning, for example around the hearth, as is the case in the site of Étiolles (Taborin 1994 - p. 136-137) or to the removal of the remains of the knapping stations (Bodu, Karlin, Ploux 1990 - p. 144-146) (fig. 5-1). 
Figure 5 - Nieborowa I, trench 4, sector II. 1 - Processing areas Mazovian blocks $n^{\circ}$ 1-12; 2 - use of space inside the camp; 3-8 - pedonculated point 9 - end-scraper; 10 - notched tool.
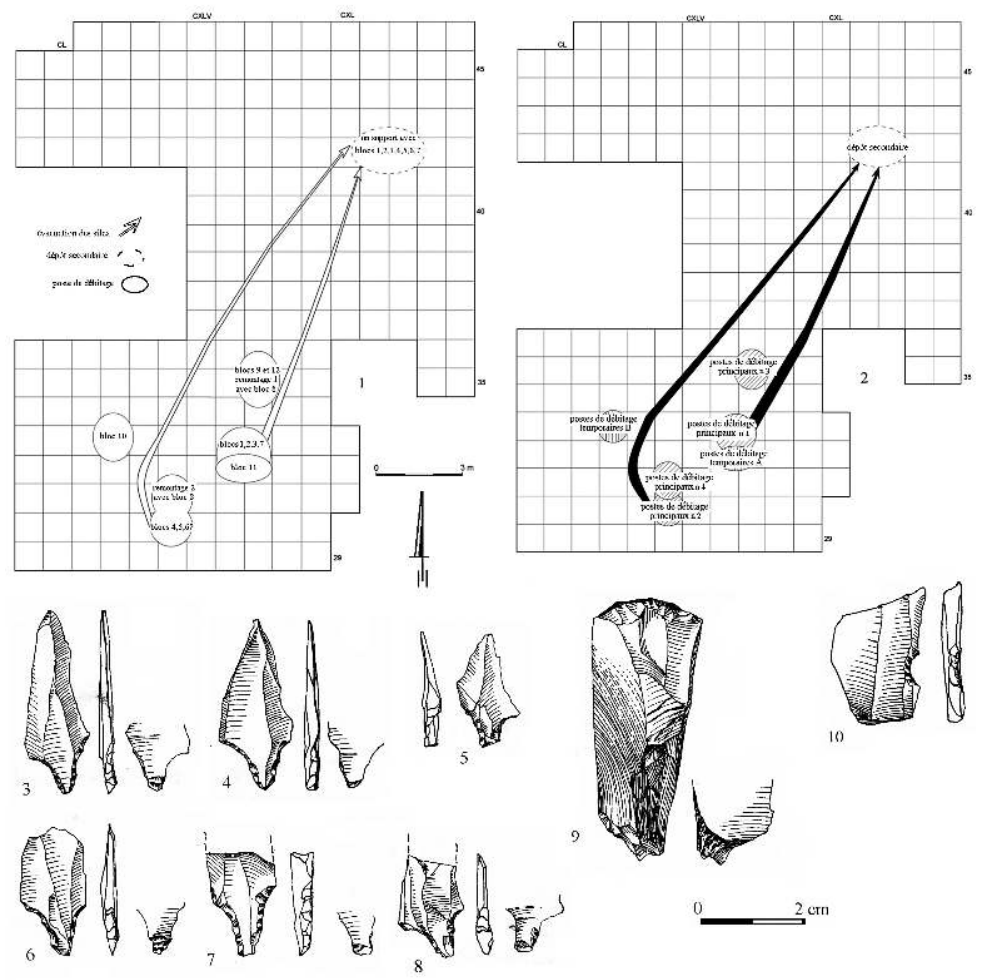

Several arguments are in support of the hypothesis that concentration $C$ is a secondary deposit, especially the absence of cores (fig. 2). Among the refitted blocks, the predominance of products from concentration C (table 2) is observed. Products from shaping up and exploitation sequences are usually separated by an object from concentration B. A main argument, refitting could be done with very small waste debris (2-3 $\mathrm{mm}$ ) from concentration $\mathrm{B}$ and from the blanks (blades and flakes) from the secondary deposit. 
Table 2 - Products making up refitted blocks.

\begin{tabular}{|c|c|c|}
\hline & $\begin{array}{l}\text { Tranchée 4, secteur I } \\
\text { dépôt secondaire }\end{array}$ & $\begin{array}{c}\text { Tranchée 4, secteur II } \\
\text { postes de débitage }\end{array}$ \\
\hline Bloc $n^{\circ} 1$ & $\begin{array}{l}\text { - mise en forme }-1 \text { pièce } \\
\text { - débitage de lames }-9 \text { pièces } \\
\text { - ravivages de plan de frappe et } \\
\text { surface débitée }-3 \text { pièces }\end{array}$ & $\begin{array}{l}\text { - nucléus - } 1 \text { pièce } \\
\text { - fragment de nucléus }-1 \text { pièce } \\
\text { - débitage de lames }-2 \text { pièces } \\
\text { - ravivage de plan de frappe - } 1 \\
\text { pièce } \\
\text { - débris - } 3 \text { pièces }\end{array}$ \\
\hline Bloc $n^{\circ} 2$ & $\begin{array}{l}\text { - mise en forme - } 3 \text { pièces } \\
\text { - débitage de lames - } 12 \text { pièces } \\
\text { - ravivage de plan de frappe - } \\
1 \text { pièce. }\end{array}$ & $\begin{array}{l}\text { - nucléus - } 2 \text { pièces } \\
\text { - débitage de lames - } 1 \text { pièce } \\
\text { - débris retouché - } 1 \text { pièce }\end{array}$ \\
\hline Bloc $n^{\circ} 3$ & $\begin{array}{l}\text { - débitage de lames - } 14 \text { pièces } \\
\text { - débris - } 3 \text { pièces }\end{array}$ & $\begin{array}{l}\text { - nucléus }-2 \text { pièces } \\
\text { - débris - } 1 \text { pièce }\end{array}$ \\
\hline Bloc $n^{\circ} 4$ & $\begin{array}{l}\text { - mise en forme }-5 \text { pièces } \\
\text { - débitage de lames - } 2 \text { pièces }\end{array}$ & $\begin{array}{l}\text { - nucléus }-2 \text { pièces } \\
\text { - mise en forme }-1 \text { pièce } \\
\text { - débris }-2 \text { pièces }\end{array}$ \\
\hline Bloc n 5 & $\begin{array}{l}\text { - mise en forme }-1 \text { pièce } \\
\text { - débitage de lames }-8 \text { pièces }\end{array}$ & $\begin{array}{l}\text { - nucléus - } 1 \text { pièce } \\
\text { - débris - } 4 \text { pièces }\end{array}$ \\
\hline Bloc $n^{\circ} 6$ & $\begin{array}{l}\text { - débitage d'éclats }-1 \text { pièce } \\
\text { - ravivage de plan de frappe - } \\
1 \text { pièce }\end{array}$ & $\begin{array}{l}\text { - nucléus - } 1 \text { pièce } \\
\text { - débitage d'éclats - } 3 \text { pièces } \\
\text { - débris - } 1 \text { pièce }\end{array}$ \\
\hline Bloc $n^{\circ} 7$ & $\begin{array}{l}\text { - ravivages de surface debitée - } \\
1 \text { pièce } \\
\text { - débitage de lames - } 6 \text { pièces }\end{array}$ & - nucléus - 2 pièces \\
\hline
\end{tabular}

The debitage stations, both those drawn by the planigraphy and those reconstructed by the refitting, differ from each other by the degree of flint density and the number of knapped cores. For this reason, they were classified into two groups: the main debitage stations that operated throughout the duration of the camp, and the temporary knapping station located generally on the edge of camp (Bodu, Karlin, Ploux 1990 - p. 146). The main debitage stations are numbered from 1 to 4 ; the temporary stations are designated by the letters A and B (fig. 5-1, 2). As for the chronological relationships between these stations, it is likely that the older ones, which were in use at the same time, were stations 1 and 2, judging by the presence of debitage products in the flint accumulation. If, however, one were to accept that the older stations were 3 and 4 , the accumulation should have yielded at least a few isolated remains from block 8 .

\subsection{2 - Trench 9}

The lithic material uncovered in this trench (fig. 6-1) belongs to various chronological phases of occupation: Palaeolithic stage - Mazovian assemblages (fig. 6); Mesolithic stage - Janislavician culture and Bronze Age - Trzcianician culture. 
Figure 6 - Nieborowa, trench 9. 1 - Mapping of finds; 2 - refitted block $n^{\circ} 1 ; 3$ - pedonculated point (Palaeolithic artifacts are in green, Mesolithic in blue).

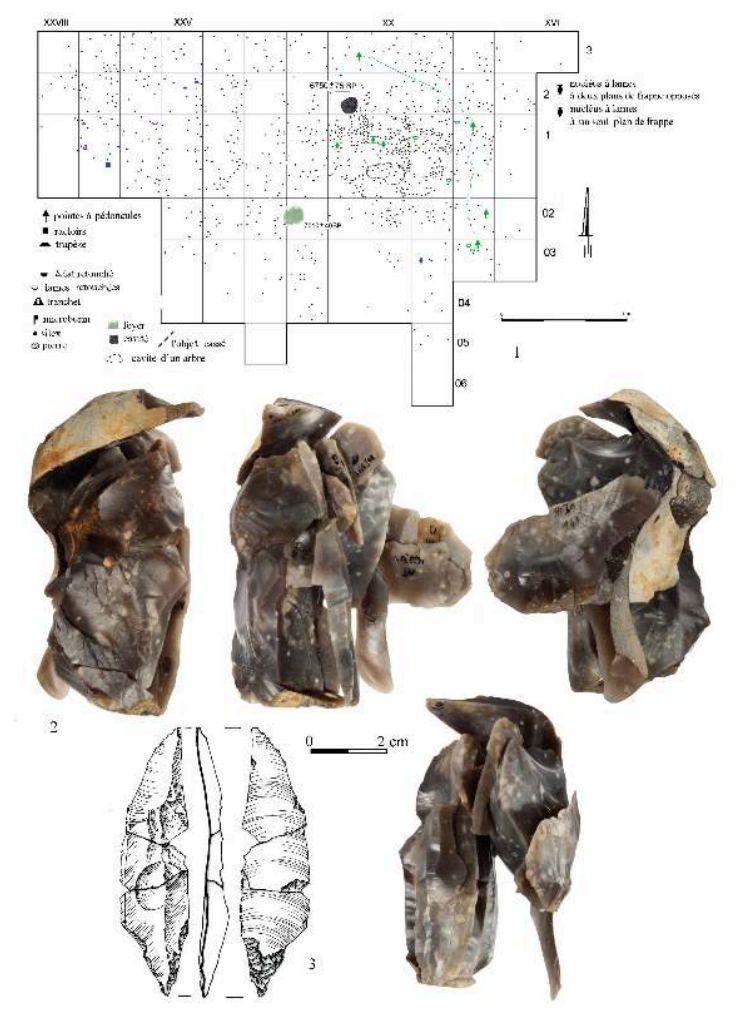

The archaeological remains of the Mazovian occupation phase appear as a 12 sq. $\mathrm{m}$ lithic concentration in which flints are rather regularly spread out. The camp is the remain of an occupation developed in two stages.

Laminar cores with two striking platforms were worked: the refitting indicate that they went through the entire fashioning cycle, from the preparation of the two striking platforms and the debitage surface up to the final use.

The artefacts from the first stage of use were removed and placed around the first debitage station as evidenced by the distribution of the products from the refitted block 1 (fig. 6-2; fig 7-1). Its different elements came from the surface layer as well as from trenches 2 and 9 but most were in trench 9. The connection network between these objects present a particularly difficult configuration and concentrates around two more recent debitage stations. It is difficult to imagine that the circular distribution reproduces the actual location of the flint, so we are led to believe that a desire to get rid of the waste products to make room for a future knapping station was at the origin of all these later developments. To our great regret, all the flint lying on the ground having been picked up, it was not possible to establish the number of knapping stations or their spatial relationships. 
Figure 7 - Nieborowa, trench 9. Mazovian. Plan of location refitting flint : 1 - refitted bloc $n^{\circ} 1 ; 2-$ refitted block $n^{\circ} 43-$ refitted block $n^{\circ} 2$ and $3 ; 4-$ use of space inside the camp.

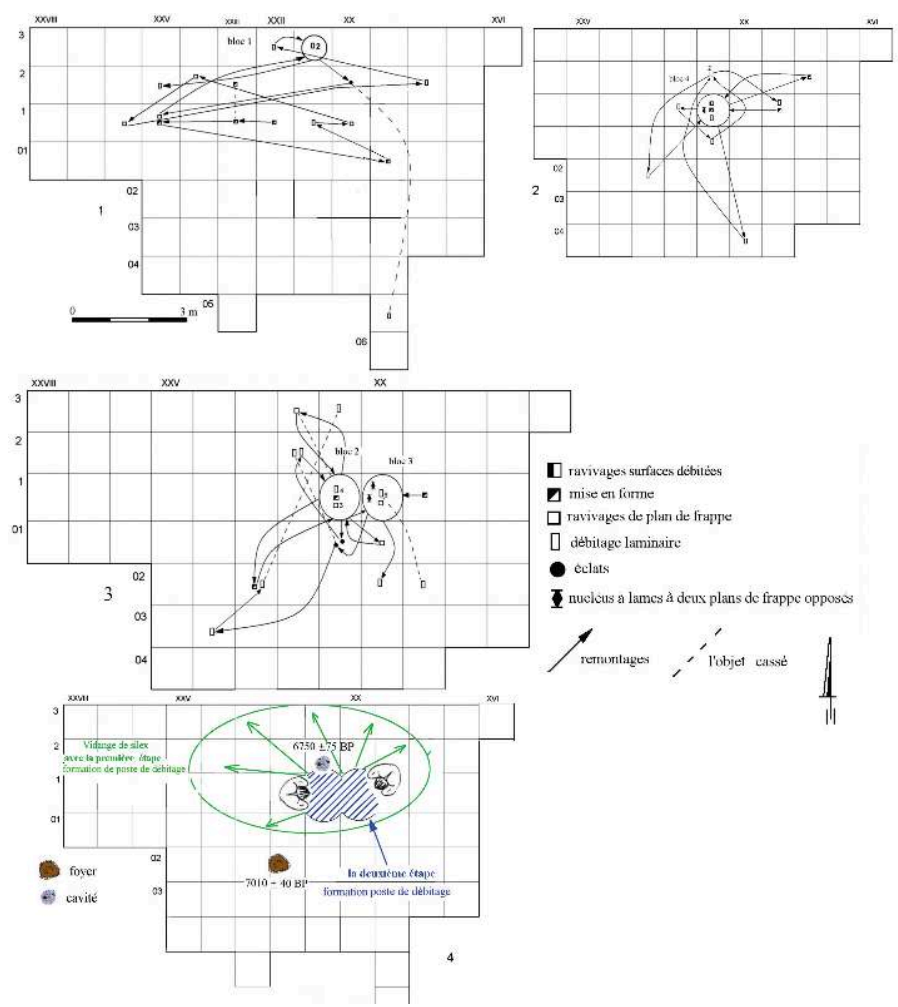

31 The second step of use of the place was marked by the creation of two debitage stations close to one another as shown by the dispersion of elements from blocks 2, 3 and 4 (fig. $7,2-3)$. The location of these two most recent stations on a previously cleared area is an extra argument in favour of the thesis of their contemporaneity (fig. 7-4). A similar spatial pattern was observed in the final Palaeolithic camp of Ślęża 11/12 (Bronowicki, Bobak, 2003 - p. 24).

\section{2 - Mesolithic occupation, Janislavice culture (classical industries without trapezes)}

\subsection{1 - Trench 4 Sector 1}

Sector I reveals two distinct concentrations of flint: concentration A, with occupation remains attributed to the Janislavice and Lusacian cultures, and an accumulation of artefacts indicated by the letter $\mathrm{C}$, containing Mazovian assemblages (Swiderian culture) (fig. 8). 
Figure 8 - Nieborowa I. Mapping of finds in trench 4, sector I. Palaeolithic artifacts are in green, Mésolithic in blue, Néolithic and metal ages, in red).

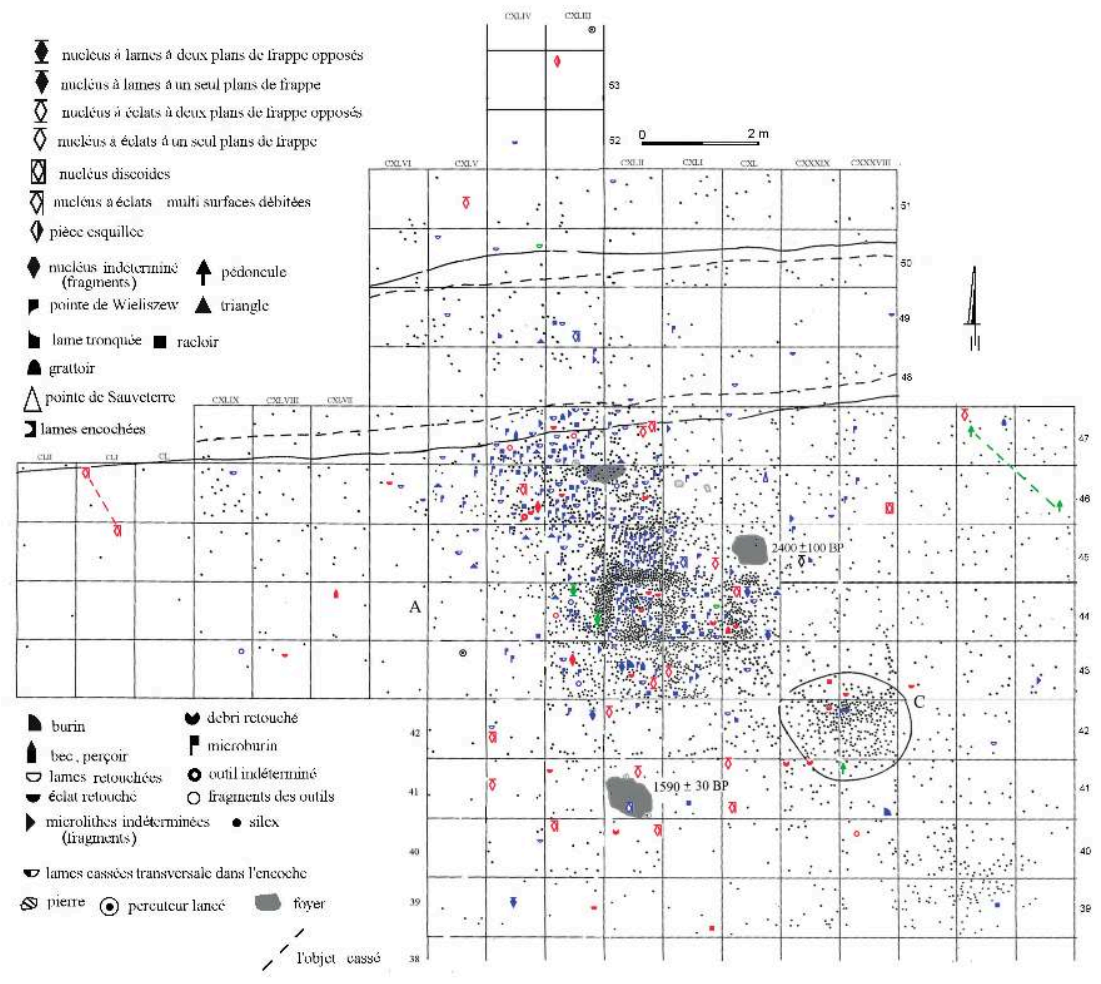

The remains of the Janislavician occupation appeared as a circa 25 sq. m concentration of flint designed by the letter A. It contained the cores, flakes, blades and tools (table 3).

Most of the findings, including many blades, were uncovered in its central part (fig. 9-3). Two accumulations, south and north, are clearly emerging in the distribution of the tools along the edge of the concentration. They concern in particular the scrapers and retouched flakes that hardly appear in the central part. Both concentrations have a similar number of tools and typological composition (table 4). Microburins are present in both concentrations, but also in the central part where they form two separate accumulations. 
Table 3 - List of the janislavian artifacts flint.

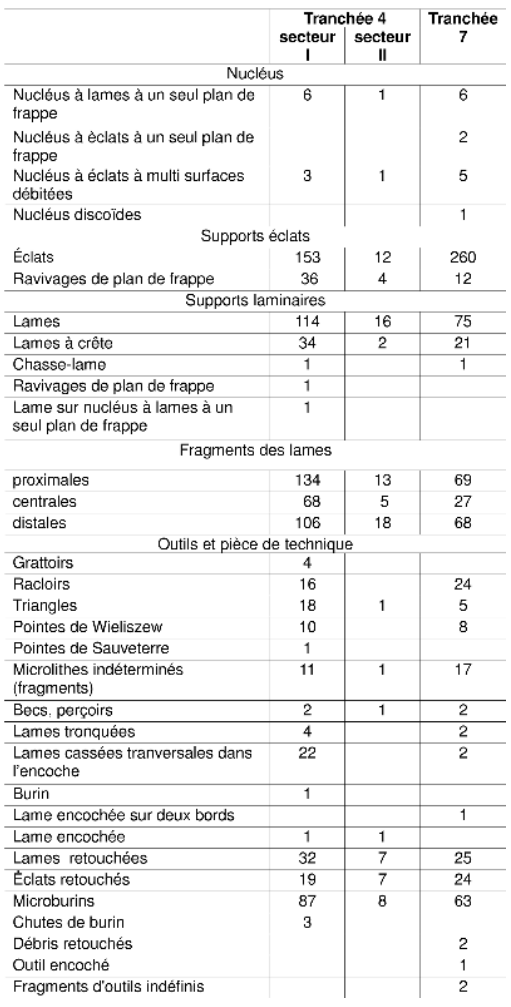

Table 4 - Nieborowa I, trenches 4 and 7. Janislavian culture. Comparison of flint inventory.

\begin{tabular}{|c|c|c|c|c|c|c|}
\hline \multirow[b]{2}{*}{ Outils } & \multicolumn{3}{|c|}{$\begin{array}{c}\text { Tranchée 4, secteur I } \\
\text { campement mésolithique }\end{array}$} & \multicolumn{3}{|c|}{$\begin{array}{c}\text { Tranchée } 7 \\
\text { campement mésolithique }\end{array}$} \\
\hline & $\begin{array}{c}\text { Territoire } \\
\text { domestique } \\
\text { du sud }\end{array}$ & $\begin{array}{l}\text { Poste de } \\
\text { débitage }\end{array}$ & $\begin{array}{c}\text { Territoire } \\
\text { domestique } \\
\text { du nord }\end{array}$ & $\begin{array}{c}\text { Territoire } \\
\text { domestique } \\
\text { du sud }\end{array}$ & $\begin{array}{l}\text { Poste de } \\
\text { débitage }\end{array}$ & $\begin{array}{c}\text { Territoire } \\
\text { domestique du } \\
\text { nord }\end{array}$ \\
\hline $\begin{array}{l}\text { Pointes de } \\
\text { Wieliszew }\end{array}$ & + & + & + & + & + & + \\
\hline Triangles & + & + & + & + & + & + \\
\hline $\begin{array}{l}\text { Lames } \\
\text { tronquées }\end{array}$ & + & - & + & + & - & - \\
\hline $\begin{array}{l}\text { Pointe de } \\
\text { Sauveterre }\end{array}$ & - & - & + & - & - & - \\
\hline $\begin{array}{l}\text { Lame } \\
\text { encochée }\end{array}$ & & + & & & & \\
\hline Racloirs & + & - & + & + & - & + \\
\hline Grattoirs & + & + & + & - & - & - \\
\hline Burins & + & - & - & - & - & - \\
\hline $\begin{array}{l}\text { Becs, } \\
\text { perçoirs }\end{array}$ & + & - & + & + & - & + \\
\hline $\begin{array}{l}\text { Lame } \\
\text { encochée } \\
\text { sur les deux } \\
\text { bords }\end{array}$ & - & - & - & + & - & - \\
\hline $\begin{array}{l}\text { Outils } \\
\text { encochés }\end{array}$ & - & - & - & - & - & + \\
\hline $\begin{array}{l}\text { Microlithes } \\
\text { indéterminés } \\
\text { (fragments) }\end{array}$ & + & + & + & + & + & + \\
\hline Mircoburins & + & + & + & + & + & + \\
\hline
\end{tabular}

The refitted blocks can be divided into two categories: the first ones illustrate the manufacture of microliths (fig. 11-5 to 11) as well as the shaping up and the 
exploitation of blade cores (fig. 10-1, 2; fig.11-4) or the resharpening of the striking platforms (fig. 11-2, 3), the second ones, the debitage of flakes (fig.10-3, 4; fig. 11- 1, fig. 12-1 to 3$)$.

The refitting links from the manufacturing of microliths are within the artefacts concentration and between them and the south and north concentrations. There is however, no direct connection between these two concentrations (fig. 9-1).

Figure 9 - Nieborowa I, trench 4, sector I. Janislavian culture. 1-2 - Plan of location of refittings flint; 3 - differents counts of Janislavian blades from particular meters.
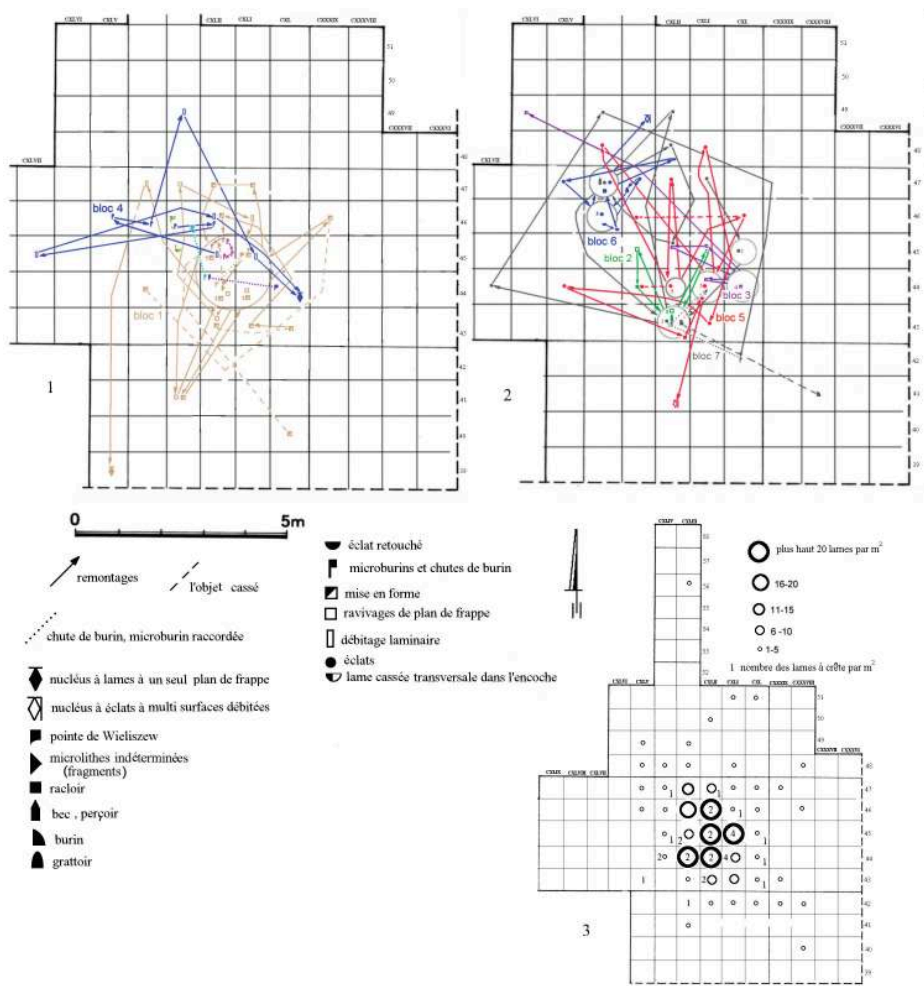

The flake debitage draws a network in two distinct places (fig. 9-2): the first one, next to the hearth where blocks 6 and 7 were worked (fig. 9-2), and the second one, on the edge of the central concentration where the artefacts knapped from block 5 were found. This quite readable distribution between two areas of flake debitage is obscured by the dispersion of the artefacts from block 7 . The spatial distribution of these elements shows that this last block was worked in both areas (fig. 9-2).

Within the flint concentration attributed to the Janislavice culture, three structures can clearly be distinguished: two accumulations of flint -south and north- and a concentration containing the largest number of objects. This distribution corresponds to various areas of activity. The central part was occupied by the principal debitage station (main workshop), while the southern and northern units constituted areas of domestic activities (Boroń 2004 - p. 12-14). 
Figure 10 - Nieborowa I, trench 4, sector I. Janislavian Culture. 1 - refitted block $n^{\circ} 1 ; 2$ - core from block $n^{\circ} 1 ; 3$ - refitted block $n^{\circ} 6 ; 4$ - core from block $n^{\circ} 6$.

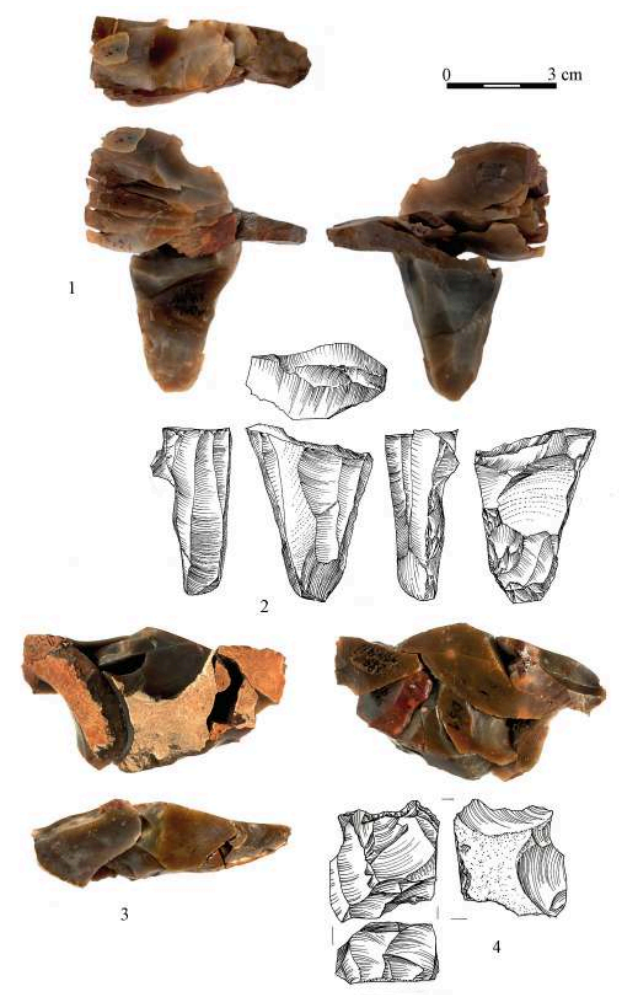

Figure 11 - Nieborowa I, trench 4, sector I. Janislavian culture. 1 - refitted block $n^{\circ} 5 ; 2$ - refitting of the platform rejuvenation; 3 - side-scrapers ; 4 - single palteform core for blades; 5-9 - refitting of the Wieliszew points; 10-11 - refitting of the microburin.
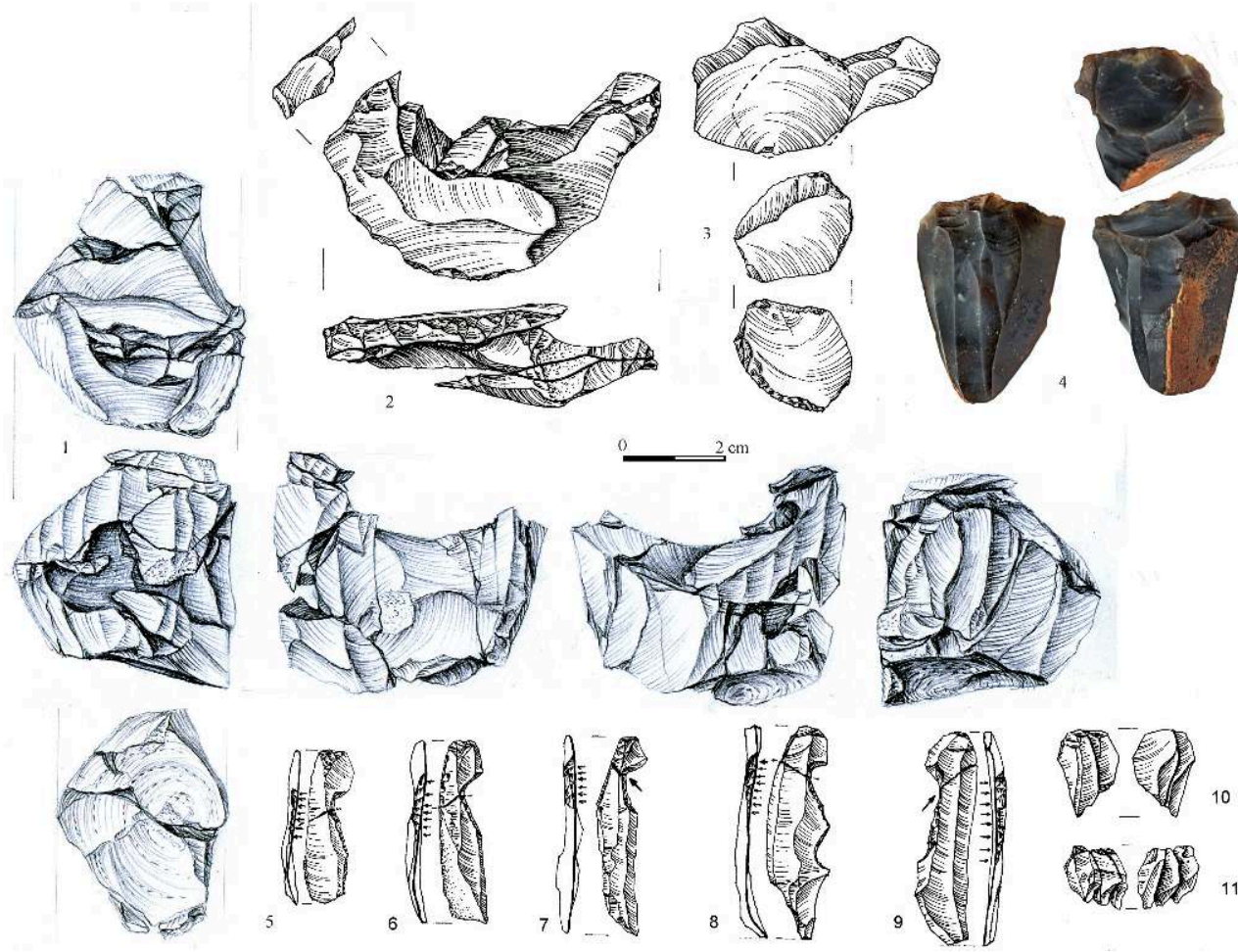


\section{Main debitage station (workshop)} diagram of blades, crested blades and refitting lines allowed identifying within this unit two distinct debitage zones of blades secondarily used in the manufacture of microliths. The remains of this activity appear as two accumulations of microburins located nearby the places of blade debitage. This station was probably the main microliths manufacturing place, which seems to be confirmed by block 1 (fig. 10-1) on which it was possible to associate a Wieliszew point and two microburins (fig.11, 7-10). areas, as evidenced by the distribution of products from block 4 (fig. 9-1).

This station was also a place of flake debitage, as the remains deposited later show. The secondary exploitation of a core, from which blades came from (block 5) (fig. 11-1), validates the hypothesis of an accumulation of artefacts in two stages, most likely in connection to the change of the flint exploitation mode in this station (blade debitage, then flake debitage).

\section{Areas of domestic activities}

They are located south and north of the main workshop. The tools are fairly evenly distributed; the northern concentration also has a hearth. However, there is no reliable indicator for finding that the activity areas were specialized in blade debitage, yet this seems suggested by the presence of blades at these locations. Moreover, the refitting of blocks 6 and 7 (fig. 9-2) shows that the remains of the exploitation of flakes in the northern concentration are an exception and that those found have a very specific characteristic. The absence of specific artefacts deposits from block 7 (fig. 12) indicates that the debitage was done in stages.

\subsection{2 - Trench 4 Sector II}

- Material attributed to the Janislavician Culture

The deposition of Janislavician material adjoined by the North to the debitage stations attributed to the Mazovian occupation. It covered an area of about $10 \mathrm{sq.} \mathrm{m}$ (fig. 2). This area has hardly yielded any objects reflecting an intense working of flint. Two blocks could be refitted (fig. 13-2, 7), whose fragments (retouched blades) were from the Janislavician concentration of zone I (fig.13 -1). The small number of artefacts (barely two microliths, fig. 13-8), the lack of real concentration, as well as the lines of refitting connecting the two concentrations of zone I and II suggest that it was a satellite space used during the functioning of the main camp in the area I. Similar spatial relationships between two concentrations, separated but contemporary have been observed on the Azilian site of Varennes (Pasty, Alix, Pelletier, Combes 2011, fig. 12, 13) and the Magdalenian site of Verberie (Audouze, Cahen, Keeley, Schmider 1981 - p. 135). 
Figure 12 - Nieborowa I, trench 4, sector I. Janislavian culture. 1 - perforator; 3 - burin; 4 - refitted block $n^{\circ} 7$.

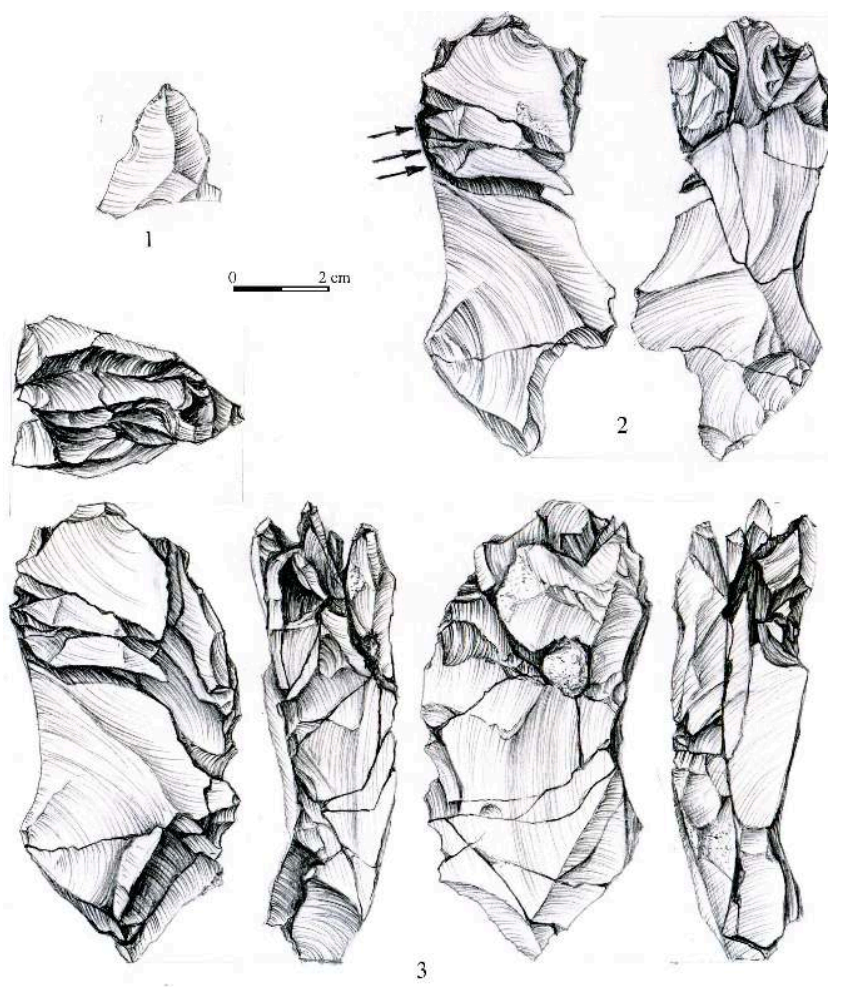

Figure 13 - Nieborowa I, trench 4, sector II. 1 - Janislavian culture. Plan of location refitting flint between sectors I and II; 2 - refitted block $n^{\circ} 1 ; 3-5$ - elements of the refitted block $n^{\circ} 1 ; 6-$ perforator from blocl $n^{\circ} 2 ; 7$ - single platform core for blades from block $n^{\circ} 2 ; 8$ - triangle.

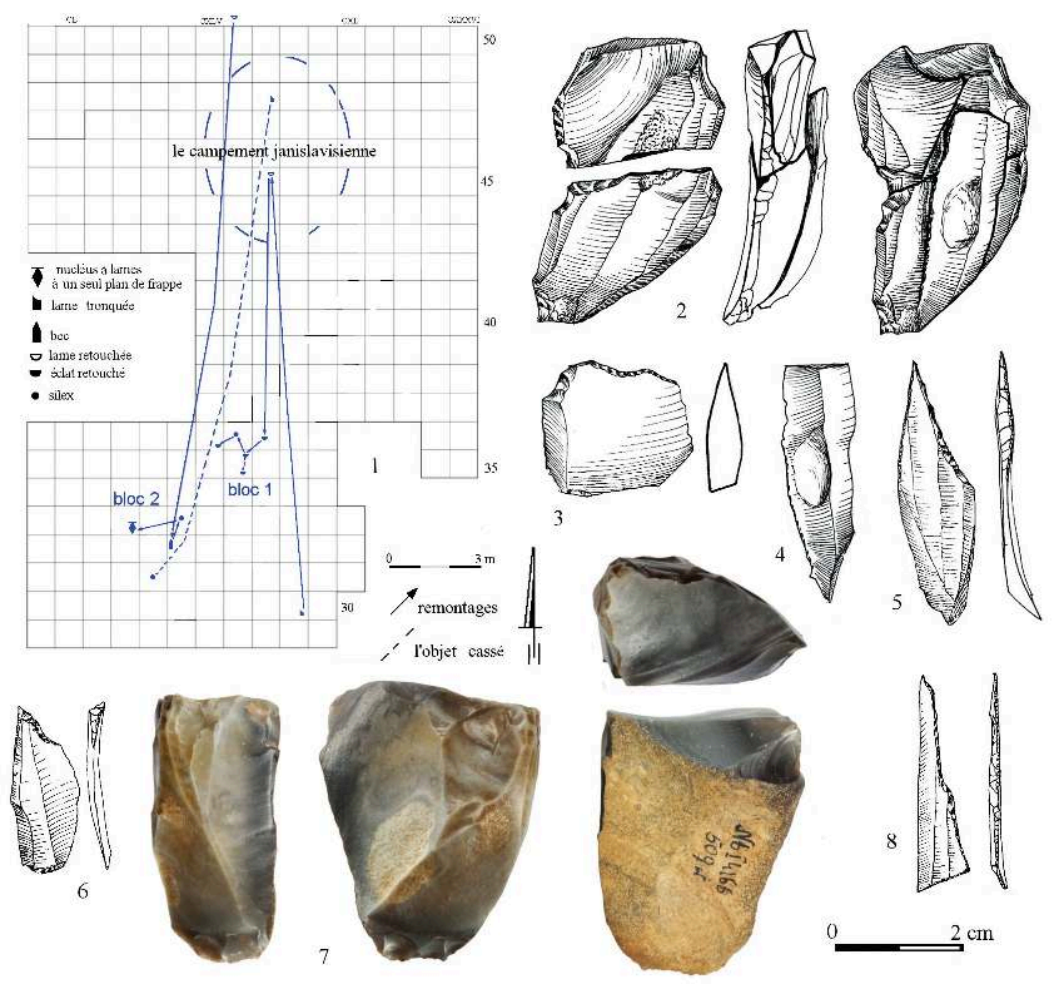


Figure 14 - Nieborowa I, trench 7. Mapping of finds. Mesolithic artifacts are in blue.

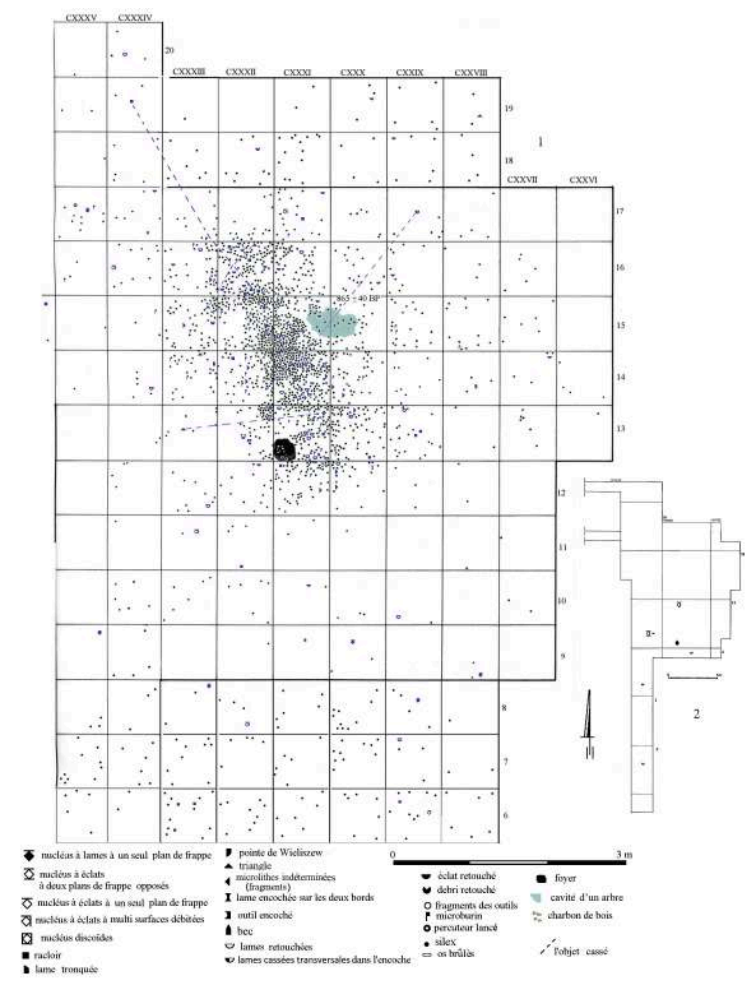

44 Two hearths were discovered in the area II. The analysis of the charcoals collected in one of them yielded the radiocarbon date of $2,185 \pm 30 \mathrm{BP}$. The second hearth, located in the squares 31/32 (CXLVI / CXLVII) is of major interest because of its location as it is found between the concentration of artefacts attributed to the Janislavician culture and the debitage station belonging to the Mazovian occupation. This hearth has yielded a group of burnt Mazovian objects (fig. 2). Stratigraphic relationships between the hearth and the deposit of the lithic material - Mazovian and Janislavician - can be established on the basis of the analysis of the data provided by the refitting. Any time connection needs to be excluded immediately between the hearth and the first stage of the accumulation of the Mazovian material cleared and piled about $10 \mathrm{~m}$ away from the hearth and in which there was no burnt flint. This shows that the hearth was later than the first Mazovian occupation and must be linked to the second stage of accumulation of the lithic material or Janislavician occupation.

\subsection{3 - Trench 7}

The excavation of the trench 7 uncovered a concentration approximately 20 sq. $\mathrm{m}$ large (fig. 14-1) of flint artefacts attributed to the Janislavician culture. Most of them were observed at the centre of this concentration. The density diagram of blades shows that they are more numerous in the centre and that, as one gets away, their number decreases significantly (fig.15-1). However, the flakes are quite regularly dispersed over a much larger surface than the very centre of the concentration (fig. 15-2). The largest accumulation of flint mostly yielded microliths and microburins. In the northern and southern parts, besides the microliths, tools on flake and on blade were also discovered. Table 4 (quantitative data of tools in the Janislavice concentrations) shows that in the 
northern and southern parts of the concentration the same types of tools appear (from the typological point of view).

Figure 15 - Nieborowa I, trench 7. Janislavian culture. 1 - differents count of Janislavian blades from particular meters; 2 - differents count of Janislavian blades from particular meters; 3-4 refitting of microlithic; 5 - fragmentation of blades; 6 - flake with retouched or unworked front and concaves sides; 7 - side-scraper from block $n^{\circ} 9 ; 8$ - refitted block $n^{\circ} 9 ; 9$ - core from block $n^{\circ} 6$; 10 - refitted block $n^{\circ} 6$.

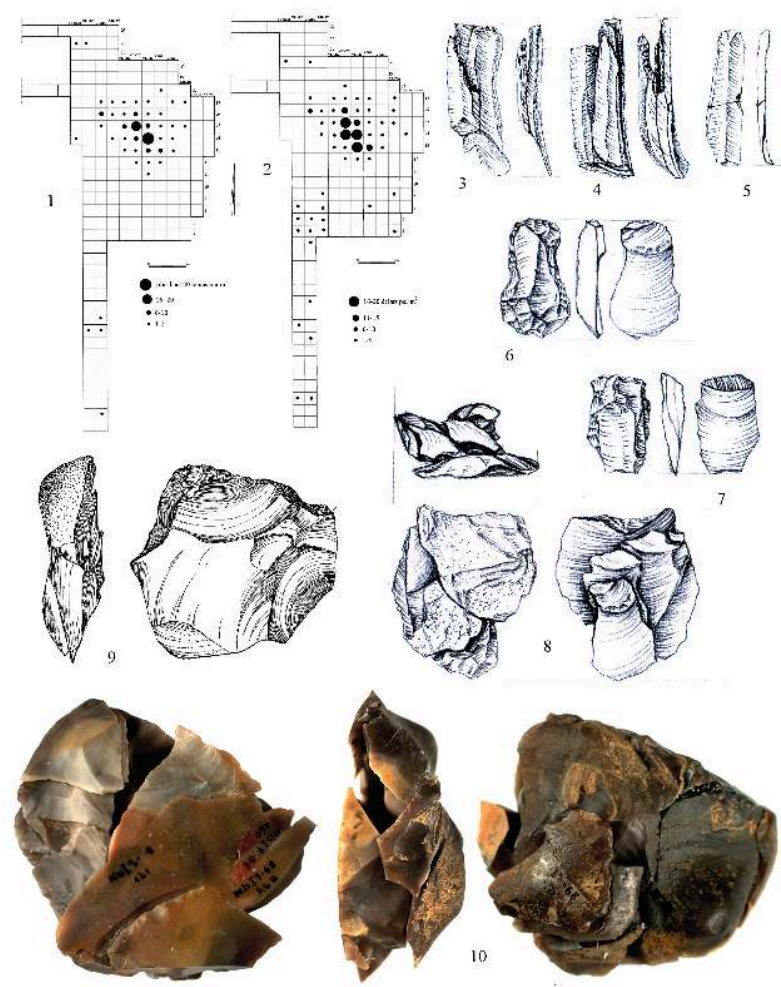

The analysis of the links between the artefacts from ten refitted blocks shows that the lines most often connect the central part of the concentration to the northern or southern areas. The lines connecting these two areas together are very rare (fig. 16-1.2). 
Figure 16 - Nieborowa I, trench 7. Janislavian culture: 1-2 - Plan of location refitting flint ; 3 trench 4, sector I: the spatial organization of the Mesolithic camp; 4 - trench 7: the spatial organization of the Mesolithic camp.

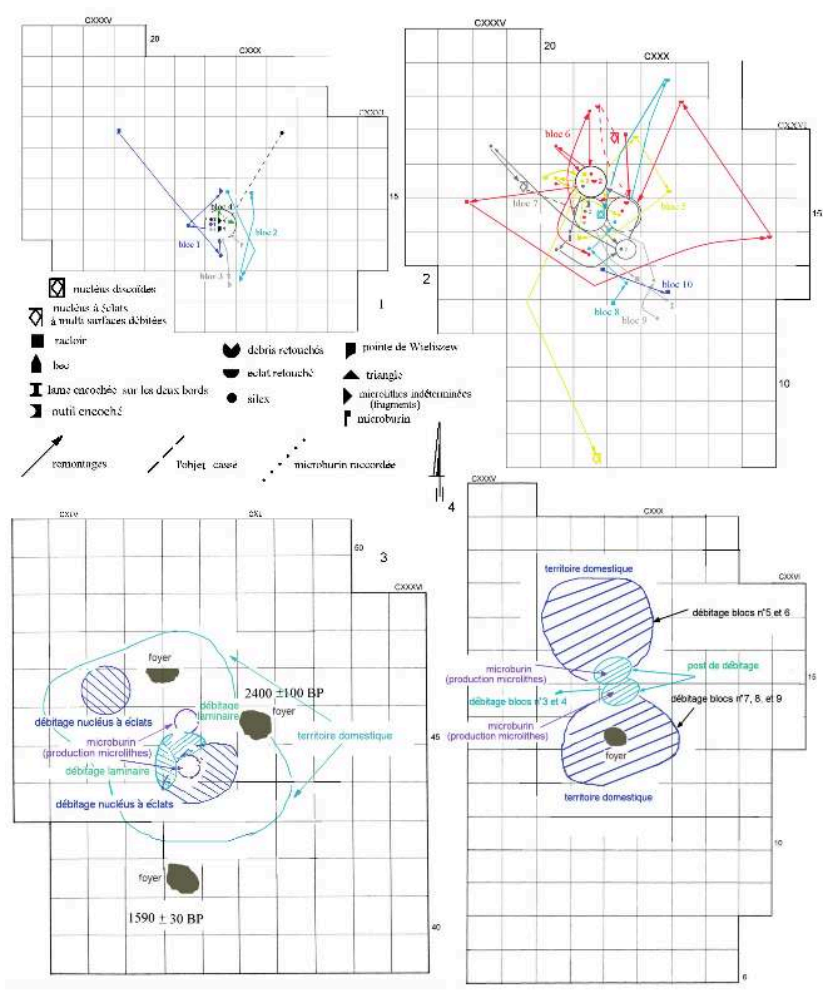

47 The data provided by the distribution of the stone tools, the density diagrams of the blades and flakes and by the refitting helped highlight three spatial units, as in the Janislavician concentration of trench 4, zone I.

At the centre of this concentration, there is a domestic debitage station where laminar cores were mainly worked and where microliths were manufactured (fig. 15-3 to 5; fig. 16-1). The distribution of the artefacts from blocks 1, 2, 3 and 4, as well as of the blades, allows assuming that in this domestic workshop, the laminar debitage was done in two different locations.

The areas adjacent to the debitage station of the northern and southern sides could be defined as areas of domestic activities. The nature and importance of these areas are determined by the presence, in one of them, of a hearth identified from wood charcoal and burnt bones and small burnt animal bones (fig. 14).

The economic activity of these two areas is related to the exploitation and manufacturing of tools on flakes, to the manufacturing of microliths from blades brought from the workshop and to flake debitage. The large size of the area in which the flakes from block 6 (fig. 15 -10), 7 and 9 (fig. 15- 6 to 8) are found suggests that the core debitage was done ad hoc, depending on the demand of blanks. It is possible to infer that the cores were worked in stages. This operating system makes it difficult to accurately identify the places of debitage.

51 Since both units have a similar spatial structure, it is reasonable to expect that the northern part of the concentration also has a hearth. However, no trace of wood charcoal was discovered there. 


\subsection{4 - Trench 9}

Despite the small number of lithic remains, this occupation has a very complicated spatial configuration from a functional point of view. In addition to the tools that are in the western part of the trench, two structures, a hearth and a pit located in the eastern part of the trench, are part of this unit.

The absence of laminar blanks, of cores and tools of daily use (end scrapers, side scrapers) on the one hand and the presence of domestic structures of the type of hearth and pit on the other hand, seem to prove that the Mesolithic remains of the trench make only part of the camp that has not been fully explored.

\section{3 - Postjanislavician occupation}

Trench 2, measuring 278 sq. $\mathrm{m}$ in surface, was explored during the 1964-1965 campaigns. The spatial analysis concerned mostly the western part of the trench in which there was a Mesolithic flint concentration (fig. 17) spreading over an area of approximately $25 \mathrm{sq}$. $\mathrm{m}$. It is characterized by a fairly regular distribution of tools and flint, with a denser concentration of flint (30 to 40 per sq. $\mathrm{m}$ ) in its central part (XL XXXVIII, 3-4) (table 5) (fig. 17). As for the tools, their distribution is recorded on a much larger area, over $45 \mathrm{~m}^{2}$. Unearthed in square 4 , small burnt animal bones suggest the location of the hearth.

Table 5 - List of the postjanislavian artifacts flint from trenches 2 and 3.

\begin{tabular}{|c|c|c|}
\hline & Tranchée 2 & Tranchée 3 \\
\hline \multicolumn{3}{|c|}{ Nucléus } \\
\hline $\begin{array}{l}\text { Nucléus à lames à un seul plans } \\
\text { de frappe }\end{array}$ & 1 & \\
\hline $\begin{array}{l}\text { Nucléus à èclats à un seul plans } \\
\text { de frappe }\end{array}$ & 5 & \\
\hline $\begin{array}{l}\text { Nucléus à èclats à multi surfaces } \\
\text { débitées }\end{array}$ & 10 & \\
\hline Nucléus indéterminé (fragments) & 2 & \\
\hline \multicolumn{3}{|c|}{ Supports éclats } \\
\hline Éclats & 294 & $90^{*}$ \\
\hline Ravivages de plan de frappe & 7 & \\
\hline \multicolumn{3}{|c|}{ Supports laminaires } \\
\hline Lames & 19 & \\
\hline Lames à crête & 5 & 1 \\
\hline \multicolumn{3}{|c|}{ Fragments de lames } \\
\hline proximale & 17 & 2 \\
\hline centrale & 8 & 2 \\
\hline distale & 18 & 2 \\
\hline \multicolumn{3}{|c|}{ Outils et pièces de technique } \\
\hline Grattoirs & 11 & \\
\hline Racloir & 77 & 6 \\
\hline Trapèzes & 5 & 2 \\
\hline Becs & 6 & \\
\hline Lames tronquées & 8 & \\
\hline $\begin{array}{l}\text { Lames cassées tranversale dans } \\
\text { l'encoche }\end{array}$ & 5 & \\
\hline Burins & 2 & \\
\hline Outils mixtes & 3 & \\
\hline Lames avec retouches continues & 8 & \\
\hline Lames encochées & 1 & \\
\hline Lames retouchées & 29 & 4 \\
\hline Éclats retouchés & 45 & 4 \\
\hline Denticulés & 1 & \\
\hline Microburin & 9 & \\
\hline Chutes de burin & 1 & \\
\hline Débris retouchés & 4 & \\
\hline Fragments d'outils indéfinis & 25 & \\
\hline
\end{tabular}

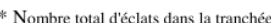


Figure 17 - Nieborowa I, trench 2. Mapping of finds.

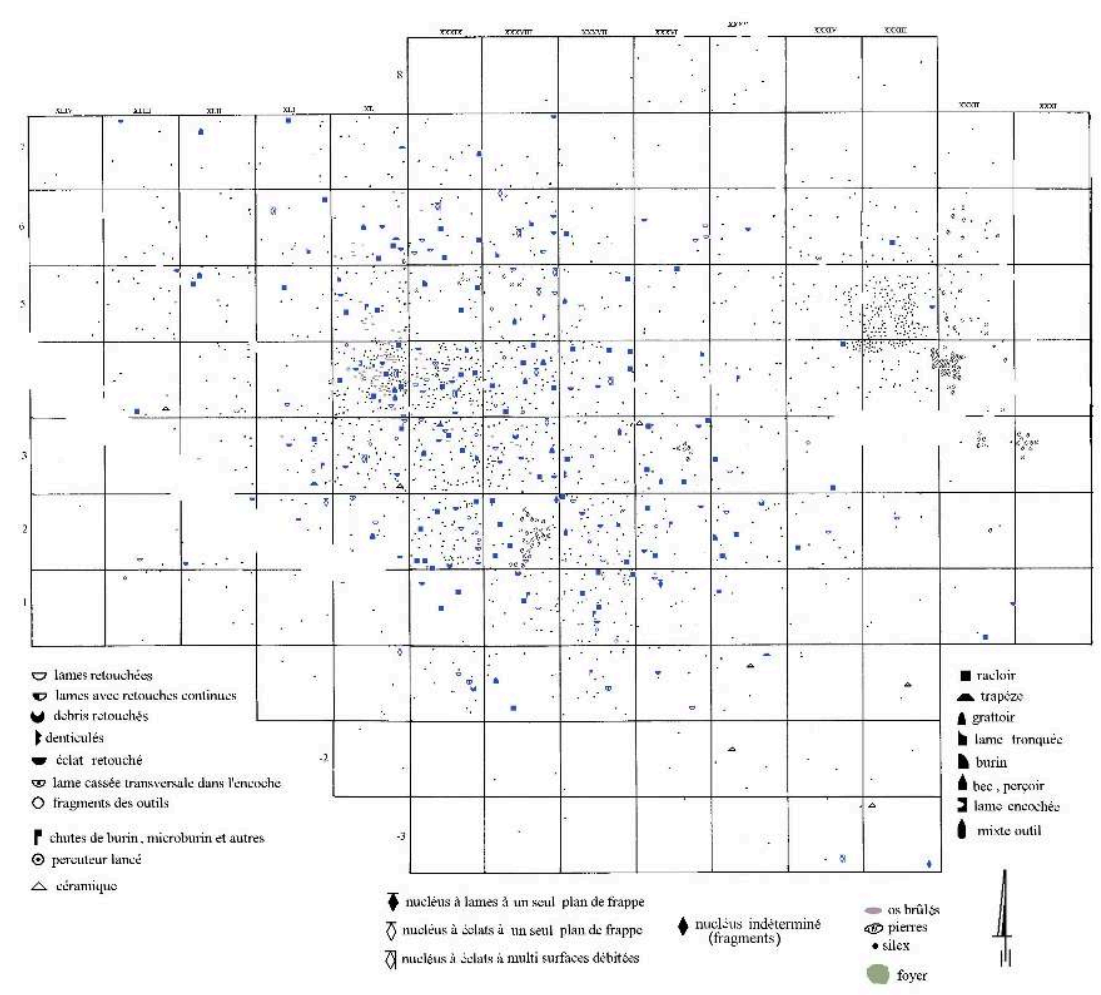

The refitting lines of artefacts form a network that is located in the northern part of the stony area around the hearth, in a circle of 2-3 $\mathrm{m}$ in diameter (fig. 18). The network is much less dense around a concentration of burnt stones in the southern part, which likely results from the absence of refitting rather than from a less intense economic activity. The refitting lines present in both parts of the flint concentration (north and south) are rare. The location of tools (burins, beaks - fig. 19-3) and waste from tool manufacturing (burin spalls, microburins- fig. 19-4) concentrated around the hearth in the northern part of the stony area seems to indicate not only the place of the manufacture of tools but also of their use.

However, it is worth noting the absence of flint knapping workshops. Indeed, the blanks forming parts of the refitted blocks did not form clearly defined concentrations but were scattered over a fairly large area (fig. 18). That is why we are unable to state with precision the places of debitage, even for the isolated cores.

The nodules used to produce flake cores measured, for most, about $60-70 \mathrm{~mm}$ (fig. 19-1), and no blades cores, with the exception of one specimen, is probably due to the transformation on a flake core (fig. 19-2).

The presence of two separate networks that constitute the refitting lines of artefacts proves that this large paved space corresponds to two spatial units, each with a central hearth. The space around the two hearths has different areas of economic activity: flint debitage, manufacture and use of tools. Both structures are characterized by similar tool groups from a typological point of view, with the exception of trapezes that appear only in the northern part of the concentration (fig. 20). 


\subsection{1 - Trench 3}

59

The spatial distribution of the lithic material is quite uniform over the entire area of the trench, without concentration areas (fig. 21.1).

The analysis of the Mesolithic tools distribution revealed two distinct deposits. The first contains a toolkit on flakes, the second laminar tools (fig. 21-1).

Within the first deposit, a block was refitted from elements from only two distinct groups: the scrapers and the flakes (fig. 21-2,3). This is not usual, the elements of refitted blocks being usually dispersed over larger surfaces (fig.7- 2, 3; 9-1,2;18).

62 The concentration of scrapers indicates the location of their use or their manufacture because it is difficult to imagine that they could have been discarded to form this accumulation.

3 Given that the dispersion of the laminar tools and the tools on flakes is different, it is possible to assume that we have two distinct areas for domestic activities using assemblages of concrete tools as is the case in the Magdalenian site of Cepoy (Wenzel, Jagu 2010, fig. 11 - p. 80).

\section{2 - Interpretation}

\section{1 - Palaeolithic Occupation}

\subsection{1 - Mazovian camps}

64 The Mazovian camps differ by the flint knapping organization that takes place in workshops (knapping stations) specializing particularly in the manufacture of blades. At Nieborowa I, the workshops were located in trenches 4 and 9. The archaeological remains make it possible to observe that in these two places the accumulation of the lithic material took place in two stages. It has been noted that the manufacturing waste corresponding to the first phase of the occupation had been cleared, and also that the clearing of the place was done in different ways. Thus, in trench 4 , the objects deposited in one place were transported and stacked in another place about $10 \mathrm{~m}$ away from the primary deposit (fig. 5-1, 2), while in trench 9, the clearing up of the station was done systematically and the artefacts were placed around the place of debitage (fig. 7-4). The systematic clearing of accumulated waste in workshops should be considered as a cyclical activity in the camps that have undergone several phases of occupation (Bodu, Karlin, Ploux 1990 - p. 146). 
Figure 18 - Nieborowa I, trench 2. Mesolithic. Plan of location of refitting flint.

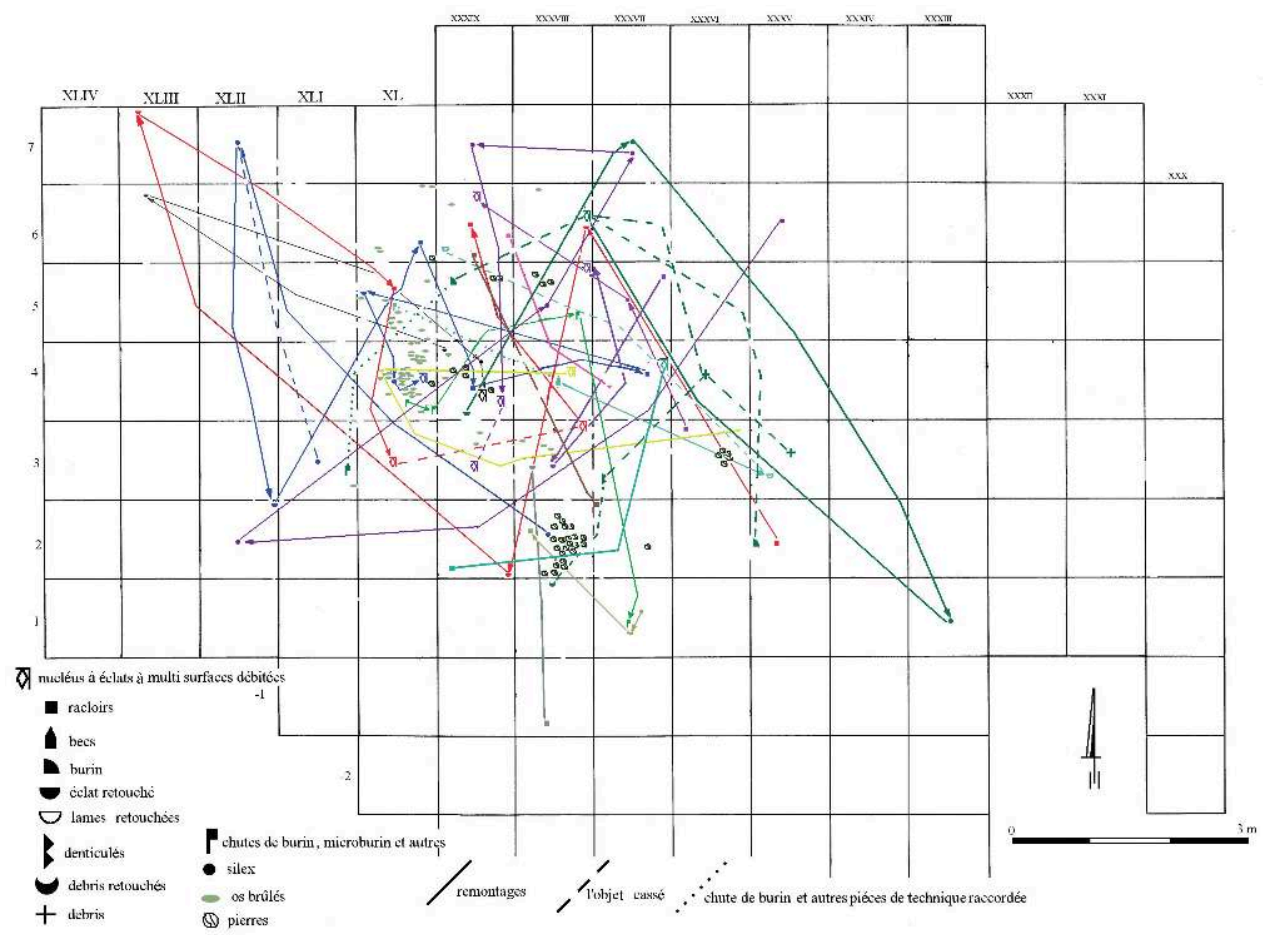

As both trenches yielded a very scarce lithic material (tools) and no obvious concentrations, it is impossible to identify in this part real areas of domestic activities (Keeley, 1991 - p. 266-267).

In trench 4 , the tools were scattered around the untreated flint debitage stations. It should be noted that this applies in particular to hafted points, one of which was in the flint accumulation, which is an indication to suggest that their production and probably also the repair of weapons were done in the workshops and not around the hearths (Cahen, Karlin, Keeley Van Noten 1980 - p 223; Carr 1991 - p. 244). 
Figure 19 - Nieborowa I, trench 2. Mesolithic. 1 - refitted block; 2 - refitted block; 3 - reffiting perforator from waste products; 4 - refittings of microburin; 5 - single platform core for blades; 6-8 - blades with continuous retouch.

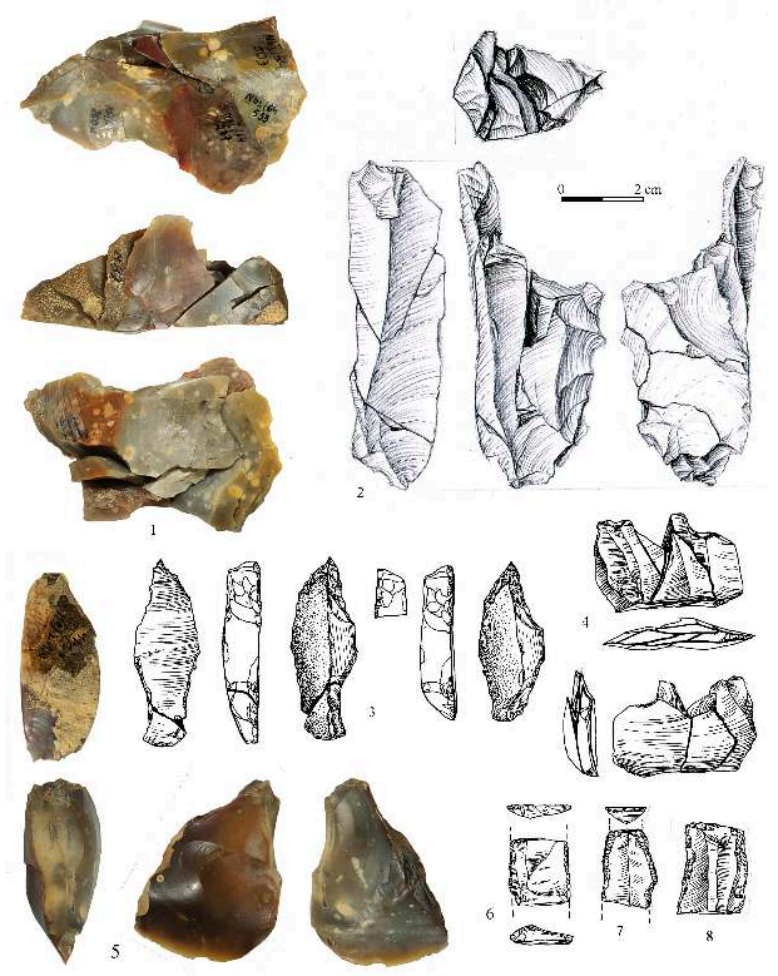

During the use of the camps, in each of them two separate but contemporary debitage stations were set up, just a few meters from each other (trench 4, fig. 5-2) or side by side (trench 9, fig. 7-4). These differences in the occupation of space can correspond to two types of camps. In the first, two families are working on two separate territories and in the second two knappers, sitting next to each other, are working the flint. The knapped blades are whether transformed into hafted points, whether stored for use by groups of hunters. 
Figure 20 - Nieborowa I, trench 2. Synthetic plan of the spatial organization.

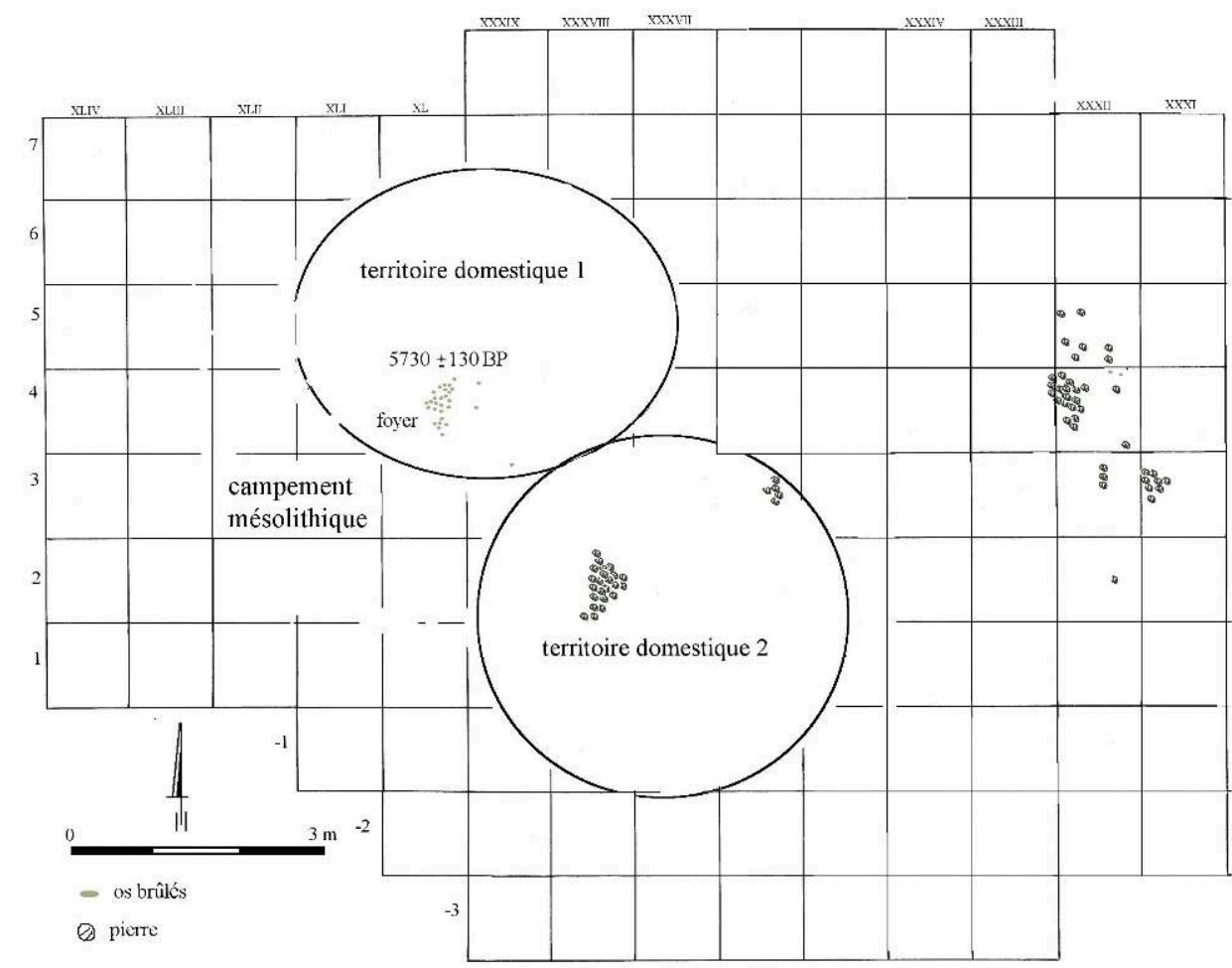

\section{2 - Mesolithic Occupation}

\subsection{1 - Janislavician Camps}

The episodes of Janislavician occupation whose remains were unearthed in the trenches 4 and 7 at Nieborowa I have a similar model of space organization, characterized by the presence of two spatial units on the north-south axis. These include a common domestic knapping station, in a central position, and to the south and north of the workshop, areas of domestic activities (fig. 16-3, 4). 
Figure 21 - Nieborowa I, tranchée 3.1 - mapping of finds; 2 - the spatial organization of the Mesolithic camp; 3 - refitted block.

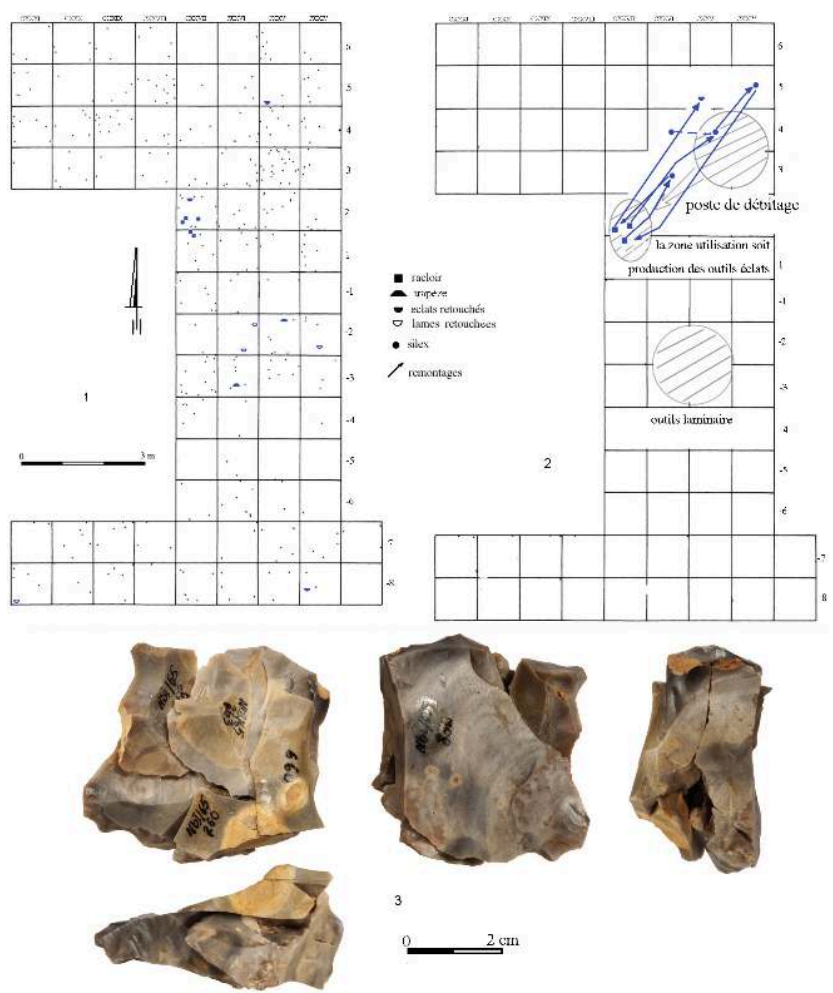

The workshop, well defined in surface, was the place of debitage of blade cores (main activity), but also the primary place of manufacture of microliths. Two distinct concentrations of microburins discovered within the workshop, the remains of the last step of the tool manufacturing (microliths), seem to indicate the continuity of the technological process but also the existence of two locations of blade cores debitage very close to each other.

The areas of domestic activities located in the southern and northern parts were places of use, repair and additional manufacturing of microliths, as evidenced by the microburins and tools on flakes found there.

71 The question of determining the chronological link between these two units remains. Sites of the Maglemose culture appear to have, from this point of view, some analogies. O. Grön (1987 - p 79; 2003 - p. 700) distinguished two types of camps: some, three by four meters large with a concentration of microliths and a hearth and the others, characterized by the presence of large structures (6 x 4 meters) called "huts", with two concentrations of microliths and two hearths, representing two occupations units inhabited by "nuclear families." As for the Polish territory, the data are provided by the site of Mokracz studied by E. Niesiolowska - Śreniowska that indicates that the Mesolithic settlements dating from the third and fourth phase of the occupation are the remains reflecting the coexistence of two families (Niesiolowska Śreniowska 1998 p. 113-114).

In light of the above, it appears that the camps of the Janislavician culture discovered in trenches 4 and 7 consisted of two units of similar configuration, indicating a degree of continuity of the spatial model. A similar model of the spatial organization of 
Mesolithic camps was recorded on the site of Ruffey -sur- Seille (Seara, Lena 2002 - p. 271).

\section{Postjanislavician occupation}

\subsection{2 - Trench 2}

The Mesolithic occupation found in the trench 2 of Nieborowa I is characterized by the uniform dispersion of artefacts on the entire surface of the flint concentration. The refitting lines have identified two distinct areas of domestic activities. These units are similar in the spatial planning model: a central fireplace with an activity area around it (fig. 20). The absence of obvious concentrations, from the planigraphical and spatial point of view, of flake and blade blanks proves that the exploitation of the cores did not occur in a precise and pre-established place but was done on almost all the surface of the camp.

74 A similar organization of space - two spatial units with a central hearth in each- was observed in the Mesolithic site of Bukówna 5 (Masoj 2004 - p. 39) and the Magdalenian site of Marsangy where the D14 and H17 structures showed great similarities (Schmider 1984 - p. 176-179).

\subsection{3 - Trench 3}

The spatial structure that could be determined from the Mesolithic remains was characterized by a different horizontal dispersion of flakes, scrapers and laminar tools, which suggests the existence of two areas of activity: debitage workshop and domestic work area where tools on flakes and laminar tools were used (fig. 21-2). Similar clusters of tools on flakes were noticed on the site of Gramsbergen (Johansen, Stapert 1997/1998 - p. 42). The existence of separate laminar concentrations of tools on flakes and tools on blades can be explained by the variety of the tasks performed at different locations. The Mesolithic site of Vaenget North in Denmark can be reminded as an example where, around the fireplace located in the central part of the camp, antlers were worked while the periphery was dedicated to the working of skin (Jensen Petersen 1985 - p. 49-50). These two areas of activity have left traces in the form of two different deposits of tools: the working of antler (side scrapers) and of skin (end scrapers and blades).

\section{Conclusions}

The spatial analysis of occupations of the final Palaeolithic and Mesolithic showed significant differences in the organization and management of the camps and the flint workplaces.

In the Palaeolithic, a particular process characterizes the formation of the campsworkshops (trench 4 and 9). In archaeological sources, it is expressed by the double sequence of accumulation of the lithic material, as evidenced by obvious signs of cleaning or clearing of the debitage remains. Each episode involved two contemporary workshops. The clearing of production waste suggests that it was customary to go back several times to the same place. 
In the Mesolithic, the lithic economics of some camps presents a hierarchical model of tool manufacturing. The spatial structures observed in the trenches 4 and 7 (fig. 16-3-4) reflect this diagram that illustrates the relationship between laminar debitage and debitage on flakes. The operating mode was as follows: blade production, then processing the products into microliths that make the bulk of the toolkit (Galinski 2002- p. 320), finally, the secondary production of flakes (fig. 11-1), as evidenced among other things by the reuse of the blade cores.

The tools found at the site show that the debitage that produced them was closely connected to a flake demand. This allows to conclude the existence of a specific relationship between the flintknapper and the operations he/she performed. The flint tools were most likely used in the place where they were manufactured. Their use was limited to brief operations, sometimes only one, after which they were discarded.

The Mesolithic occupation of Nieborowa is characterized by the presence of settlements consisting of two contemporary occupation units (trenches 2, 4 and 7).

81 The study of the implantation and the organisation of the Palaeolithic and Mesolithic settlements in the microregion of Nieborowa in Lublin Polesia showed differences in their spatial organization. These differences can be explained by the choice of a specific economic model among the hunter- gatherers of the Palaeolithic and Mesolithic.

\section{BIBLIOGRAPHY}

ANDREFSKY Jr. W. 2009 - The Analysis of Stone Tool Procurement, Production, and Maintenance. Journal of Archaeological Research, 17, p. 65-103.

AUDOUZE F., CAHEN D., KEELEY L.H., SCHMIDER B. 1981 - Le site magdalénien du buisson campin à Verberie. Gallia Préhistoire, 24, p. 100-143.

BODU P., KARLIN C., PLOUX S. 1990 - Who's who ? The Magdalenian flintknappers of Pincevent, France. In : E. Cziesla, S. Eickhoff, N. Arts, D. Winter (Ed.), The big puzzle. Studies in Modern Archaeology, Bonn, p. 143-164.

BOROŃ T. 2004 - Układy przestrzenne w krzemienicach kultury janisławickiej na podstawie zespołów krzemiennych z wykopów 4 i 7 ze stanowiska Nieborowa I, gm. Sawin, woj, lubelskie. Archeologia Polski, 49, p. 7-32.

BOROŃ T. 2006 - Organizacja przestrzeni w krzemienicach mazowszańskich na przykladzie zespolów krzemiennych ze stanowiska Nieborowa I, gm. Sawin, woj. lubelskie. Archeologia Polski, 51, p. 13-41.

BRONOWICKI J., BOBAK D. 2003 - Schyłkowy paleolit i mezolit na stanowisku Ślęza 11/12, pow. Wroclaw. In : B. Gediga (Ed.), Archeologiczne Zeszyty Autostradowe, z. 2, Badania na autostradzie A 4, cz.1, Wrocław, p. 9-35.

CAHEN D. 1984 - Interprétations nouvelles pour le site paléolithique final de Meer II, Belgique. In : H. Berke, J. Hahn, C.J. Kind (Ed.), Jungpaläolithische siedlungsstrukturen in Europa, Verlag Archaeologica Venatoria, Institut für Urgeschite der Universität Tübingen, p. 241-250. 
CAHEN D., KEELEY L.K., VAN NOTEN F.L. 1979 - Stone Tools, Toolkits, and Human Behavior in Prehistory. Current Anthropology, 20, n 4, p. 661-683.

CAHEN D., KARLIN C., KEELEY L.K., VAN NOTEN F. L. 1980 - Méthodes d'analyse technique, spatiale et fonctionnelle d'ensembles lithiques. Helinium, 20, z. 3, p. 209-260.

CARR C. 1991 - Left in the Dust : Contextual Information in Model-Focused Archaeology. In : E.M. Kroll T D. Price (Ed.), The Interpretation of Archaeological Spatial Patterning. Plenum Press, New York and London, p. 221-256.

CHMIELEWSKA M. 1954 Grób kultury tardenuaskiej w Janisławicach, woj. Skierniewice, Wiadomości Archeologiczne, t. 20, z. 1, p. 23-48.

CZIESLA E. 1990 - On refitting of stone artifacts. In : E. Cziesla, S. Eickhoff, N. Arts, D. Winter (Ed.), The big puzzle. Studies in Modern Archaeology, Bonn, p. 9-44.

FIEDORCZUK J. 2006 - Final Paleolithic Camp Organization - as seen from the perspective of lithic artifacts refitting. Warszawa, IAE PAN, $167 \mathrm{p}$.

GALIŃSKI T. 2002 - Społeczeństwa mezolityczne. Osadnictwo, gospodarka, kultura łowiecka w VIII-IV tysiĄcleciu p.n.e. na terenie Europy. Seria Archeologiczna, Bibliotek Naukowa Szczecin, 406 pp. 1997 Mezolit Europy, Szczecin, 259 p.

GRÖN O. 1987 - Dwelling organization - a key to the understanding of social structure in old Stone Age societies? An example from the Maglemose culture. Archaeologia Interregionalis. New in Stone Age Archaeology, p. 63-85.

GRÖN O. 2003 - Mesolithic dwelling places in south Scandinavia : their definition and social interpretation. Antiquity, 77, p. 685-708.

GUMIŃSKI W. 1999 - Kultura Zedmar a kultura Narva. Razem czy osobno. Światowit, 1, fascykuł B, p. 59-69.

GUMIŃSKI W. 2001 - Kultura Zedmar. Na rubieży neolitu zachodniego“. In : J. Czebreszuk, M. Kryvalcevič P. Makarowicz (Ed.), Od neolityzacji do poczĄtków epoki brĄzu. Przemiany kulturowe w miĘdzyrzeczu Odry i Dniepru miĘdzy VI i II tys. przed Chr, Archaeologia Bimaris, t. 2, Wydawnictwo Poznańskie, Poznań, p. 133-154.

JENSEN. H.J., PETERSEN E.B. 1985 - A functional study of lithics from Vænget Nord, a mesolithic site at Vedbæk, N. E. Sjælland. Journal of Danish Archaeology, 4, p. 40-51.

JOHANSEN L., STAPERT D. 1997/1998 - Two epi-ahrensburgian sites in the Northern Netherlands : Oudehaske (Friesland) and Gramsbergen (Overijssel). Paleohistoria, 39-40, p. 1-87.

KEELEY H.L. 1991 - Tool use and spatial patterning : complications and solution. In : E.M. Kroll, T.D. Price (Ed.), The Interpretation of Archaeological Spatial Patterning, New York, Plenum Press, p. 257-268.

KOZŁOWSKI S. K. 1972 - Pradzieje ziem polskich od IX do V tysiąclecia p.n.e., Państwowe Wydawnictwo Naukowe, Warszawa.

KOZŁOWSKI S. K. 1989 - Mesolithic in Poland. A new approach, Wydawnictwa Uniwersytetu Warszawskiego, Warszawa.

KOZŁOWSKI S. K. 2007 - Mezolit - miĘdzy wschodem a zachodem. In : L. Bakalarska (ed.), Wspólnota dziedzictwa archeologicznego ziem Ukrainy i Polski. Materiały z konferencji zorganizowanej przez Ośrodek Ochrony Dziedzictwa Archeologicznego, Łańcut (26-28 X 2005 r.), Krajowy Ośrodek Badań i Dokumentacji Zabytków, Warszawa, p. 108-114. 
MASOJĆ M. 2004 - The Mesolithic in Lower Silesia in the light of settlement phenomena of the Kaczawa river basin. Studia Archeologiczne, 35.

NIESIOŁOWSKA - ŚRENIOWSKA E. 1998 - Warunki egzystencji i organizacja przestrzenna obozowiska późnomezolitycznego w Mokraczu, w Polsce Środkowej, Prace i Materiały Muzeum Archeologicznego i Etnograficznego w Łodzi. Seria Archeologiczna, nr 39, p. 65-128.

OLAUSSON D. 1986 - Intrasite Spatial Analysis in Scandinavian Stone Age Research. Papers of the Archaeological Institute University of Lund 1985-86, 6, p. 5-24.

OLIVE M. 1997 - Foyer domestique ou foyer annexe. Les modes d'occupation de l'espace des Magdaléniens d'Étiolles. Gallia Préhistoire, 39, p. 85-107.

PASTY J-F., ALIX P., PELLETIER D., COMBES P. 2011 Approche économique et spatiale du campement azilien des Varennes à Pérignat-sur-Allier (Puy-de-Dôme). Bulletin de la Société préhistorique française, 108, n. 1, p. 53-72.

SCHIFFER M.B. 1976 - Behavioral Archeology, Academic Press New York, San Francisco, London, $215 \mathrm{p}$.

SCHILD R. 1980 - Introduction to dynamic technological analysis of chipped stone assemblages. In : R. Schild (Ed.), Unconventional Archaeology. New approaches and goals in Polish archaeology, Ossolineum Wrocław, Warszawa, Kraków, Gdańsk, p. 57-85.

SCHILD R. 1984 - Terminal Paleolithic of the North European Plain : A review of lost chances, potential, and hopes. Advances in World Archaeology, 3, p. 193-274.

SCHILD R. 1996 - The North European Plain and Eastern Sub-Balticum between 12, 700 and 8, 000 BP. In : L.G. Straus, B.V. Eriksen, J.M. Erlandson, D.R. Yesner (Ed.), Humans at the end of the ice age. The archaeology of the pleistocene-holocene transition, New York-London, p. 129-157.

SCHILD R., MARCZAK M., KRÓLIK H. 1975 - Późny Mezolit. Próba wieloaspektowej analizy otwartych stanowisk piaskowych. Zakład Narodowy Imienia Ossolińskich. Wroclaw, Warszawa, Gdańsk, Kraków, 262 p.

SCHMIDER B. 1984 - Les habitations magdaléniennes de Marsagny (vallée de L'Yonne, France). In : H. Berke, J. Hahn, C. J. Kind (Ed.), Jungpaläolithische siedlungsstrukturen in Europa, Verlag Archaeologica Venatoria, Institut für Urgeschite der Universität Tübingen, p. 169-180.

SÉARA F., A. LENA 2002 - Organisation spatiale. In : F. Séara, S. Rotillon, C. Cupillard (Ed.), Campements mésolithiques en Bresse jurassienne. Choisey et Ruffey-sur-Seille, Documents d'archéologie française, 92, Éditions de la Maison des Sciences de l'Homme, Paris, p. 211-309.

SZYMCZAK K. 2003 - Kultura janislawicka/ krĄg kultur janislawickich - rozwój poglĄdów i stan badań. In : E. Kawałkowa (Ed.), Kultura janisławicka w Polsce pótnocno-wschodniej i na terenach sĄsiednich, OstrolekĘka, p. 7-17.

TABORIN Y. 1994 - Environnements et habitats magdaléniens dans le centre du Bassin parisien. Documents d'archéologie française, 43, Éditions de la Maison des Sciences de l'Homme Paris, $189 \mathrm{p}$.

TOMASZEWSKI A. J. 1986 - Metoda składanek wytworów kamiennych i jej walory poznawcze. Archeologia Polski, 31, p. 239-273.

WENZEL S., JAGU D. 2010 - L'habitat autour du foyer T5/T6 dans le gisement du Magdalénien Final de Cepoy (Loiret, France). In : M. Połtowicz-Bobak, D. Bobak (Ed.), The Magdalenian in Central Europe. New finds and concepts, Mitel, Rzeszów, p. 71-83. 


\section{ABSTRACTS}

The remains of assemblages Masovian camps found in trenches 4 and 9 are flint workshops. In both cases we perceive two phases of flint material cumulation. The settlements of Janislavian culture in Nieborowa are characterized by household camps of much differentiated spatial organization. In trench 4, sector I and in trench 7 the spatial structure of Janislavian culture concentrations looked as follows : the central place was taken by the flint knapping area - the place of the blade core exploitation and microliths production and two concentrations of tools one in the north and other in the south (areas of household activity). Different is the spatial organization of postjanislavian camp complexes. In trench 2 two separate spatial plans with fires placed in their central parts were found, around which the area of household activity was determined (cores exploitation, tools production). In trench 3 the horizontal distribution of tools and flakes to the existence of two separate activity zones : the workshop (flake cumulation) and the zone of household activities (flakes and blades).

L'analyse spatio-temporelle des campements de l'Âge de pierre dans la Polésie de Lublin illustre deux phases d'occupation: le Paléolithique supérieur (ensembles mazoviens) et le Mésolithique (culture de Janislavice). Les campements mazoviens des tranchées 4 et 9 constituent les vestiges d'ateliers de débitage de silex. Dans les deux cas, l'accumulation du matériel lithique s'est opérée en deux temps. L'occupation de la culture janislavicienne à Nieborowa se caractérise par des campements domestiques à l'organisation spatiale diversifiée. Dans la tranchée 4, secteur I ainsi que dans la tranchée 7 , la structure des concentrations janislaviciennes se présentait de la manière suivante : la place centrale était occupée par le poste de débitage principal de nucléus et de fabrication de microlithes tandis qu'au sud et au nord, se trouvaient les aires d'activités domestiques. L'organisation spatiale des campements postjanislaviciens était différente. Dans la tranchée 2, ont été découvertes deux organisations spatiales distinctes dont les parties centrales étaient occupées par un feu de camp et dont l'espace était dévolu à l'exploitation des nucléus et à la production d'outils. Dans la tranchée 3, la planigraphie des outils et du matériel lithique démontre qu'il y avait bien deux zones d'activités distinctes: une zone de fabrication (concentration d'éclats) et une zone d'activité domestique (présence d'outillage sur éclats et d'outils laminaires).

\section{INDEX}

Keywords: Poland, Nieborowa site, terminal Palaeolithic, Mesolithic, spatial analysis Mots-clés: Pologne, Nieborowa, Paléolithique final, Mésolithique, analyse spatiale

\section{AUTHOR}

\section{TOMASZ BORON}

Section Âge de pierre, Institut d'Archéologie et d'Ethnologie, Académie Polonaise des Sciences, Al. Solidarności 105, 00-140 Varsovie (Pologne) - boron@iaepan.edu.pl 